\title{
Electro-Fenton, UVA Photoelectro-Fenton and Solar Photoelectro-Fenton Treatments of Organics in Waters Using a Boron-Doped Diamond Anode: A Review
}

\author{
Enric Brillas* \\ Laboratori d'Electroquímica dels Materials i del Medi Ambient (LEMMA), Departament de Química Física, Facultat de \\ Química, Universitat de Barcelona, Martí i Franquès 1-11,08028 Barcelona, Spain. brillas@ub.edu
}

Received January 10th, 2014; Accepted March 11th, 2014.

\begin{abstract}
The characteristics and applications of electrochemical advanced oxidation processes (EAOPs) like electro-Fenton (EF), UVA photoelectro-Fenton (PEF) and solar PEF (SPEF) with a boron-doped diamond (BDD) anode are reviewed. Their oxidative properties are based on the attack of ${ }^{\bullet} \mathrm{OH}$ formed at the anode surface and in the medium from Fenton's reaction between cathodically generated $\mathrm{H}_{2} \mathrm{O}_{2}$ and added $\mathrm{Fe}^{2+}$. The illumination with UVA light in PEF and sunlight in SPEF enhances the degradation process due to the photolysis of complexes of $\mathrm{Fe}$ (III) with generated carboxylic acids. Examples on the removal of industrial chemicals, pesticides, dyes and pharmaceuticals by these EAOPs using bench-scaled stirred tank reactors and pre-pilot plants are described. The influence of experimental variables on the mineralization and energetic parameters is detailed. The decay kinetics of pollutants and the evolution of intermediates are discussed. The SPEF process shows the best performance, being the most potent EAOP tested.
\end{abstract}

Keywords: Electro-Fenton, mineralization, oxidation products; photoelectro-Fenton, sunlight, UVA light, water treatment.

\section{Introduction}

A high number of synthetic organics like industrial chemicals, pesticides, dyes and pharmaceuticals are released daily into large volumes of wastewaters, thus entering into natural waters where they accumulate in the aquatic environment [1-4]. This contamination proceeds from urban, industrial and agricultural human activities and cannot be significantly removed by conventional wastewater treatment plants because most synthetic organics are recalcitrant, highly stable to sunlight irradiation and with large resistance to microbial attack and temperature. Low amounts of many synthetic organics, usually at $\mu \mathrm{g} \mathrm{L}^{-1} \mathrm{lev}$ el, have been detected in rivers, lakes, oceans and even drinking water all over the world. Since water is essential for the subsistence of all the living beings, this pollution remains a pervasive threat. Research efforts are being made to remove organics from waters and wastewaters using safe, effective and economical technologies in order to avoid their toxic consequences and potential hazardous health effects on the living beings.

Over the past two decades, many advanced oxidation processes (AOPs) have attracted increasing interest for the efficient destruction of toxic and/or biorefractory pollutants from waters [2, 5-10]. AOPs are powerful environmental friendly technologies involving chemical, photocatalytic, photochemical, elec-
Resumen. Este artículo revisa las características y aplicaciones de procesos electroquímicos avanzados de oxidación (PEAOs) como el electro-Fenton (EF), el fotoelectro-Fenton UVA (FEF) y el FEF solar (FEFS) con un ánodo de diamante dopado con boro (DDB). Sus propiedades oxidativas se basan en el ataque del radical ${ }^{\circ} \mathrm{OH}$ formado en la superficie del ánodo y en el medio a partir de la reacción de Fenton entre el $\mathrm{H}_{2} \mathrm{O}_{2}$ generado catódicamente y el $\mathrm{Fe}^{2+}$ añadido. La iluminación con luz UVA en PEF y luz solar en FEFS mejora el proceso degradativo debido a la fotólisis de complejos de Fe(III) con ácidos carboxílicos generados. Se describen ejemplos sobre la eliminación de productos químicos industriales, pesticidas, colorantes y fármacos por estos PEAOs usando reactores de tanque agitado a pequeña escala y plantas pre-piloto. También se detalla la influencia de variables experimentales sobre los parámetros de mineralización y energéticos y se discute el descenso cinético de los contaminantes y la evolución de sus intermedios. El proceso de FEFS resulta ser el más eficiente, siendo el más potente PEAO ensayado.

Palabras clave: Electro-Fenton, mineralización, productos de oxidación, fotoelectro-Fenton, luz solar, luz UVA, tratamiento de aguas.

trochemical and photoelectrochemical methods in which hydroxyl radical $\left({ }^{\circ} \mathrm{OH}\right)$ is produced in situ as the main oxidant. The high standard reduction potential $\left(E^{\circ}\left({ }^{\bullet} \mathrm{OH} / \mathrm{H}_{2} \mathrm{O}\right)=2.80 \mathrm{~V}\right.$ vs. SHE) of this radical ensures that it can react non-selectively with most organics yielding dehydrogenated or hydroxylated derivatives, which can be in turn mineralized to $\mathrm{CO}_{2}$, water and inorganic ions [8-10]. The most typical chemical AOP is the Fenton method based on the use of a mixture of $\mathrm{Fe}^{2+}$ and $\mathrm{H}_{2} \mathrm{O}_{2}$ (Fenton's reagent) to destroy organics. The oxidation ability of this method can be significantly enhanced by irradiating the treated effluent with UV light (photo-Fenton method) or sunlight (solar photo-Fenton method) [9]. Another way to enhance the decontamination efficiency of the Fenton process is its coupling with electrochemical methods, giving rise to a large variety of electrochemical AOPs (EAOPs) [7, 8]. They present many technical advantages such as environmental compatibility, versatility, high efficiency, amenability of automation and safety because they operate at mild conditions [2]. EAOPs are mediated electrochemical treatments based on the destruction of organics at the anode and/or using the Fenton's reagent partially or completely generated from electrode reactions.

The simplest EAOP based on the destruction of organics at the anode is the electro-oxidation or anodic oxidation (AO) method. When it is also carried out with cathodic $\mathrm{H}_{2} \mathrm{O}_{2}$ genera- 
tion, it is so-called $\mathrm{AO}$ with electrogenerated $\mathrm{H}_{2} \mathrm{O}_{2}\left(\mathrm{AO}-\mathrm{H}_{2} \mathrm{O}_{2}\right)$ [7]. If Fenton's reagent is electrogenerated, the EAOPs based on Fenton's reaction chemistry are considered, which have been developed for the treatment of acidic wastewaters $[2$, $8,9]$. The most typical technique is the electro-Fenton (EF) process, where an iron catalyst is added to the effluent while $\mathrm{H}_{2} \mathrm{O}_{2}$ is produced at the cathode with $\mathrm{O}_{2}$ or air feeding. The oxidation ability of the EF method depends on the anode material and it has been found that boron-doped diamond (BDD) electrodes yield the best performance, as demonstrated firstly in our laboratory in 2004. The efficiency of EF can also be improved by combining it with the simultaneous illumination of the solution by UVA light or sunlight, corresponding to the so-called UVA photoelectro-Fenton (PEF) and solar PEF (SPEF) methods [8].

This paper aims to present a general review over the application of the EF, PEF and SPEF methods to the degradation of organic pollutants in waters using potent BDD anodes. Examples on the treatments of industrial chemicals, pesticides, dyes and pharmaceuticals are examined to show the high oxidation ability of these EAOPs. Fundamentals of these methods are initially described to better analyze their characteristics and oxidative properties.

\section{Fundamentals of the EF, PEF and SPEF Methods}

Hydrogen peroxide is a "green" chemical since it leaves oxygen gas and water as byproducts. This product is used to clean electronic circuits, delignify agricultural wastes and bleach pulp and paper and textiles, for disinfection in medical and industrial applications and as an oxidant in synthesis and wastewater treatment [11]. However, $\mathrm{H}_{2} \mathrm{O}_{2}$ can only attack reduced sulfur compounds, cyanides and certain organics such as aldehydes, formic acid and some nitro-organic and sulfo-organic compounds. The treatment of wastewaters with $\mathrm{H}_{2} \mathrm{O}_{2}$ is then limited by its low oxidation ability and for this reason, it is activated in acidic effluents with $\mathrm{Fe}^{2+}$ ion as catalyst yielding the Fenton's reagent to produce homogenous ${ }^{\circ} \mathrm{OH}$ as strong oxidant of organics in the well-known chemical Fenton method [8].

It is known since 1882 that $\mathrm{H}_{2} \mathrm{O}_{2}$ can be produced in aqueous media from the two-electron reduction of dissolved $\mathrm{O}_{2}$ gas at carbonaceous cathodes with high surface area [12]. In acidic medium, this reaction with $E^{\mathrm{o}}=0.68 \mathrm{~V}$ vs. SHE can be written as follows:

$$
\mathrm{O}_{2(\mathrm{~g})}+2 \mathrm{H}^{+}+2 \mathrm{e}^{-} \rightarrow \mathrm{H}_{2} \mathrm{O}_{2}
$$

Reaction (1) is easier than the four-electron reduction of $\mathrm{O}_{2}$ to water $\left(E^{\mathrm{o}}=1.23 \mathrm{~V}\right.$ vs. SHE). Electrochemical reduction at the cathode surface from reaction (2) and, in much lesser extent, disproportion in the bulk from reaction (3) are parasitic reactions that result in the loss of oxidant or a lowering of current efficiency [13]:

$$
\begin{gathered}
\mathrm{H}_{2} \mathrm{O}_{2}+2 \mathrm{e}^{-} \rightarrow 2 \mathrm{OH}^{-} \\
2 \mathrm{H}_{2} \mathrm{O}_{2} \rightarrow \mathrm{O}_{2(\mathrm{~g})}+2 \mathrm{H}_{2} \mathrm{O}
\end{gathered}
$$

In an undivided cell, $\mathrm{H}_{2} \mathrm{O}_{2}$ is also anodically oxidized to $\mathrm{O}_{2}$ via hydroperoxyl radical $\left(\mathrm{HO}_{2}{ }^{\bullet}\right)$ as intermediate, a weaker oxidant than ${ }^{\bullet} \mathrm{OH}$, by the following reaction $[8,10]$ :

$$
\mathrm{H}_{2} \mathrm{O}_{2} \rightarrow \mathrm{HO}_{2}^{\bullet}+\mathrm{H}^{+}+\mathrm{e}^{-}
$$

The treatment of acidic aqueous solutions by EAOPs based on Fenton's reaction chemistry involves the continuous generation of $\mathrm{H}_{2} \mathrm{O}_{2}$ from $\mathrm{O}_{2}$ directly injected as pure gas or compressed air via reaction (1). $\mathrm{O}_{2}$ is efficiently reduced at cathodes like carbon nanotubes- polytetrafluoroethylene (PTFE) $[14,15]$, carbon nanotubes immobilized onto graphite plates [16], carbon felt (CF) $[17,18]$, activated carbon fiber [19, 20], carbon- PTFE gas diffusion electrodes (GDE) [21-24] and BDD electrodes [25]. When a small quantity of $\mathrm{Fe}^{2+}$ is added to the acidic effluent, it reacts with electrogenerated $\mathrm{H}_{2} \mathrm{O}_{2}$ to generate $\mathrm{Fe}^{3+}$ and ${ }^{\bullet} \mathrm{OH}$ in the bulk from the Fenton's reaction (5) with absolute rate constant $k_{2}=76 \mathrm{M}^{-1} \mathrm{~s}^{-1}$ and optimum $\mathrm{pH}$ of 2.8 [26]:

$$
\mathrm{Fe}^{2+}+\mathrm{H}_{2} \mathrm{O}_{2} \rightarrow \mathrm{Fe}^{3+}+\cdot \mathrm{OH}+\mathrm{OH}^{-}
$$

Reaction (5) can be propagated by the catalytic behavior of the $\mathrm{Fe}^{3+} / \mathrm{Fe}^{2+}$ pair $[27,28]$. Thus, $\mathrm{Fe}^{2+}$ can be regenerated by $\mathrm{H}_{2} \mathrm{O}_{2}$ from the Fenton-like reaction (6), by $\mathrm{HO}_{2}{ }^{\bullet}$ from reaction (7) and/or by the superoxide ion $\left(\mathrm{O}_{2}{ }^{--}\right)$from reactions (8) and (9):

$$
\begin{gathered}
\mathrm{H}_{2} \mathrm{O}_{2}+\mathrm{Fe}^{3+} \rightarrow \mathrm{Fe}^{2+}+\mathrm{HO}_{2}^{\bullet}+\mathrm{H}^{+} k_{2}=3.1 \times 10^{-3} \mathrm{M}^{-1} \mathrm{~s}^{-1} \\
\mathrm{Fe}^{3+}+\mathrm{HO}_{2}^{\bullet} \rightarrow \mathrm{Fe}^{2+}+\mathrm{O}_{2}+\mathrm{H}^{+} k_{2}=2 \times 10^{4} \mathrm{M}^{-1} \mathrm{~s}^{-1} \\
\mathrm{Fe}^{3+}+\mathrm{O}_{2}^{\bullet-} \rightarrow \mathrm{Fe}^{2+}+\mathrm{O}_{2} k_{2}=5 \times 10^{7} \mathrm{M}^{-1} \mathrm{~s}^{-1} \\
\mathrm{Fe}^{3+}+\mathrm{O}_{2}^{\bullet-}+2 \mathrm{H}_{2} \mathrm{O} \rightarrow \mathrm{Fe}^{2+}+2 \mathrm{H}_{2} \mathrm{O}_{2} k_{2}=1 \times 10^{7} \mathrm{M}^{-1} \mathrm{~s}^{-1}
\end{gathered}
$$

The propagation reactions involve the production of $\mathrm{HO}_{2}{ }^{\circ}$ by reaction (10) and superoxide anion $\mathrm{O}_{2}{ }^{\circ-}$ by reaction (11), and the attack of ${ }^{\bullet} \mathrm{OH}$ to saturated or aromatic organics yielding dehydrogenated or hydroxylated derivatives by reactions (12) or (13), respectively.

$$
\begin{aligned}
& \mathrm{H}_{2} \mathrm{O}_{2}+\bullet \mathrm{OH} \rightarrow \mathrm{H}_{2} \mathrm{O}+\mathrm{HO}_{2}{ }^{\bullet} k_{2}=3.3 \times 10^{7} \mathrm{M}^{-1} \mathrm{~s}^{-1} \\
& \mathrm{HO}_{2}^{\bullet} \leftrightarrows \mathrm{H}^{+}+\mathrm{O}_{2}^{\bullet-} \mathrm{K}=4.8 \\
& \mathrm{RH}+{ }^{\bullet} \mathrm{OH} \rightarrow \mathrm{R}^{\bullet}+\mathrm{H}_{2} \mathrm{O} k_{2}=10^{7}-10^{9} \mathrm{M}^{-1} \mathrm{~s}^{-1} \\
& \mathrm{ArH}+{ }^{\bullet} \mathrm{OH} \rightarrow \mathrm{ArHOH}^{\bullet} k_{2}=10^{8}-10^{10} \mathrm{M}^{-1} \mathrm{~s}^{-1}
\end{aligned}
$$

Also, several inhibition reactions upgrade the removal of reactive ${ }^{\circ} \mathrm{OH}$, for example, its reaction with $\mathrm{Fe}^{2+}$ and its dimerization to $\mathrm{H}_{2} \mathrm{O}_{2}$ as follows:

$$
\begin{gathered}
\mathrm{Fe}^{2+}+\cdot{ }^{\circ} \mathrm{OH} \rightarrow \mathrm{Fe}^{3+}+\mathrm{OH}^{-} k_{2}=4.3 \times 10^{8} \mathrm{M}^{-1} \mathrm{~s}^{-1} \\
\cdot \mathrm{OH}+\cdot{ }^{\bullet} \mathrm{OH} \rightarrow \mathrm{H}_{2} \mathrm{O}_{2} k_{2}=5.2 \times 10^{9} \mathrm{M}^{-1} \mathrm{~s}^{-1}
\end{gathered}
$$


Interestingly, an advantage of the EAOPs compared to the chemical Fenton method is that $\mathrm{Fe}^{2+}$ is regenerated from $\mathrm{Fe}^{3+}$ reduction at the cathode by reaction (16), with $E^{\mathrm{o}}=0.77 \mathrm{~V}$ vs. SHE [8], although in an undivided electrolytic cell, $\mathrm{Fe}^{2+}$ is slowly oxidized to $\mathrm{Fe}^{3+}$ by reaction (17) [28]:

$$
\begin{aligned}
& \mathrm{Fe}^{3+}+\mathrm{e}^{-} \rightarrow \mathrm{Fe}^{2+} \\
& \mathrm{Fe}^{2+} \rightarrow \mathrm{Fe}^{3+}+\mathrm{e}^{-}
\end{aligned}
$$

In undivided electrolytic systems with a non-active BDD anode, the quicker degradation rate of organics in EF, PEF and SPEF is usually achieved at $\mathrm{pH}$ near 3. They are not only destroyed by reactive oxygen species (ROS), like ${ }^{\circ} \mathrm{OH}$ and in much smaller extent by $\mathrm{H}_{2} \mathrm{O}_{2}, \mathrm{HO}_{2}{ }^{\circ}$, etc., but also by heterogeneous $\mathrm{BDD}\left({ }^{\circ} \mathrm{OH}\right)$ produced from water oxidation by reaction (18) $[29,30]$ :

$$
\mathrm{BDD}+\mathrm{H}_{2} \mathrm{O} \rightarrow \mathrm{BDD}\left({ }^{\bullet} \mathrm{OH}\right)+\mathrm{H}^{+}+\mathrm{e}^{-}
$$

Operating at high current within the water discharge region, reactive $\mathrm{BDD}\left({ }^{\circ} \mathrm{OH}\right)$ can mineralize completely aromatics and unsaturated compounds such as carboxylic acids because it is produced in high quantity, much greater, for example, than $\mathrm{Pt}\left({ }^{\circ} \mathrm{OH}\right)$ formed at the $\mathrm{Pt}$ anode [30]. The main loss of $\mathrm{BDD}\left({ }^{\bullet} \mathrm{OH}\right)$ includes its oxidation to $\mathrm{O}_{2}$ gas via reaction (19) and its dimerization to $\mathrm{H}_{2} \mathrm{O}_{2}$ by reaction (20) due to the low adsorption ability of ${ }^{\bullet} \mathrm{OH}$ on $\mathrm{BDD}[31,32]$. Furthermore, the high oxidation ability of BDD favors the formation of other weaker oxidants like peroxodisulfate $\left(\mathrm{S}_{2} \mathrm{O}_{8}{ }^{2-}\right)$ ion from the oxidation of $\mathrm{SO}_{4}{ }^{2-}$ ion present in the electrolyte by reaction (21) and ozone by reaction (22) [30-32].

$$
\begin{gathered}
2 \mathrm{BDD}(\cdot \mathrm{OH}) \rightarrow 2 \mathrm{BDD}+\mathrm{O}_{2(\mathrm{~g})}+2 \mathrm{H}^{+}+2 \mathrm{e}^{-} \\
2 \mathrm{BDD}(\cdot \mathrm{OH}) \rightarrow 2 \mathrm{BDD}+\mathrm{H}_{2} \mathrm{O}_{2} \\
2 \mathrm{SO}_{4}{ }^{2-} \rightarrow \mathrm{S}_{2} \mathrm{O}_{8}{ }^{2-}+2 \mathrm{e}^{-} \\
3 \mathrm{H}_{2} \mathrm{O} \rightarrow \mathrm{O}_{3(\mathrm{~g})}+6 \mathrm{H}^{+}+6 \mathrm{e}^{-}
\end{gathered}
$$

The BDD anode is currently preferred in $\mathrm{AO}$ and comparison with EF, PEF and SPEF can be made using the AO- $\mathrm{H}_{2} \mathrm{O}_{2}$ method without $\mathrm{Fe}^{2+}$ addition to the polluted water.

Apart from the generation of $\mathrm{BDD}\left({ }^{\bullet} \mathrm{OH}\right)$ and ${ }^{\bullet} \mathrm{OH}$ as the main oxidizing agents, the PEF process involves the exposition of the acidic treated effluent to UV light. Artificial lamps providing UVA $(\lambda=315-400 \mathrm{~nm})$, UVB $(\lambda=285-315 \mathrm{~nm})$ and/or UVC $(\lambda<285 \mathrm{~nm})$ lights are commonly employed. The intensity and wavelength of such radiations have significant effect on the destruction rate of organic pollutants, which can be associated with: (i) a faster $\mathrm{Fe}^{2+}$ regeneration with additional - $\mathrm{OH}$ generation from photoreduction of $\mathrm{Fe}(\mathrm{OH})^{2+}$, the preeminent $\mathrm{Fe}^{3+}$ species at $\mathrm{pH} 2.8-3.5$, according to photo-Fenton reaction $(23)[8,26]$ and/or (ii) the photodecarboxylation of complexes of $\mathrm{Fe}$ (III) with generated carboxylic acids allowing the regeneration of $\mathrm{Fe}^{2+}$ from the general reaction (24). As an example, reaction (25) shows the photolytic process for $\mathrm{Fe}(\mathrm{III})-$ oxalate complexes $\left(\mathrm{Fe}\left(\mathrm{C}_{2} \mathrm{O}_{4}\right)^{+}, \mathrm{Fe}\left(\mathrm{C}_{2} \mathrm{O}_{4}\right)_{2}{ }^{-}\right.$and $\left.\mathrm{Fe}\left(\mathrm{C}_{2} \mathrm{O}_{4}\right)_{3}{ }^{3-}\right)$ [33], formed as ultimate products of aromatics.

$$
\begin{gathered}
\mathrm{Fe}(\mathrm{OH})^{2+}+h v \rightarrow \mathrm{Fe}^{2+}+\cdot \mathrm{OH} \\
\mathrm{Fe}(\mathrm{OOCR})^{2+}+h v \rightarrow \mathrm{Fe}^{2+}+\mathrm{CO}_{2}+\mathrm{R}^{\bullet} \\
2 \mathrm{Fe}\left(\mathrm{C}_{2} \mathrm{O}_{4}\right)_{\mathrm{n}}{ }^{(3-2 \mathrm{n})}+h v \rightarrow 2 \mathrm{Fe}^{2+}+(2 \mathrm{n}-1) \mathrm{C}_{2} \mathrm{O}_{4}{ }^{2-}+2 \mathrm{CO}_{2}
\end{gathered}
$$

On the other hand, the use of an energetic UVC light causes the photolysis of some organics and the generation of more ${ }^{\bullet} \mathrm{OH}$ from the following homolytic cleavage of $\mathrm{H}_{2} \mathrm{O}_{2}$ [3]:

$$
\mathrm{H}_{2} \mathrm{O}_{2}+h v \rightarrow 2 \cdot \mathrm{OH}
$$

It is noteworthy that the high electrical cost of the UV lamps utilized in PEF is the main drawback of this procedure in practice. To solve this problem, our laboratory has proposed the alternative use of the SPEF method, where sunlight, as inexpensive and renewable energy source with $\lambda>300 \mathrm{~nm}$, irradiates directly the solution $[34,35]$. The higher intensity of UV light supplied by solar radiation, along with the additional absorption at $\lambda>400 \mathrm{~nm}$, e.g., for the photolysis of $\mathrm{Fe}(\mathrm{III})-$ carboxylate complexes, improve the mineralization of SPEF compared with PEF.

The aforementioned characteristics of the EAOPs using a BDD anode and a carbon-PTFE $\mathrm{O}_{2}$-diffusion cathode were confirmed by determining the accumulation of generated $\mathrm{H}_{2} \mathrm{O}_{2}$ in solution. As an example, Figs. 1a and b illustrate the scheme of a $2.5 \mathrm{~L}$ pre-pilot flow plant and its filter-press BDD/GDE electrochemical reactor of $20 \mathrm{~cm}^{2}$ electrode area, respectively, which have been used for the comparative study of the degradation behavior of some aromatics by $\mathrm{AO}-\mathrm{H}_{2} \mathrm{O}_{2}, \mathrm{EF}$ and SPEF [34]. Fig. 1c depicts the change of $\mathrm{H}_{2} \mathrm{O}_{2}$ concentration during the electrolysis of $2.5 \mathrm{~L}$ of a $0.05 \mathrm{M} \mathrm{Na}_{2} \mathrm{SO}_{4}$ solution at $\mathrm{pH}$ 3.0 in the above plant at different current density [35]. In the absence of contaminants and iron ions $\left(\mathrm{AO}-\mathrm{H}_{2} \mathrm{O}_{2}\right.$ conditions), a gradual accumulation of $\mathrm{H}_{2} \mathrm{O}_{2}$ can be observed up to attain a steady concentration, which increased linearly in 17,35 and 54 $\mathrm{mM}$ with rising current density in $50 \mathrm{~mA} \mathrm{~cm}^{-2}$ (curve $c$ ), 100 $\mathrm{mA} \mathrm{cm}{ }^{-2}$ (curve $b$ ) and $150 \mathrm{~mA} \mathrm{~cm}^{-2}$ (curve $a$ ). This trend suggests that all electrode reactions involved are faradaic and the steady $\mathrm{H}_{2} \mathrm{O}_{2}$ concentration was reached just when its generation rate from reaction (1) became equal to its oxidation rate at the anode from reaction (4). In contrast, when $100 \mathrm{mg} \mathrm{L}^{-1}$ of the herbicide mecoprop and $0.5 \mathrm{mM} \mathrm{Fe}^{2+}$ were added to the solution operating under SPEF conditions, the $\mathrm{H}_{2} \mathrm{O}_{2}$ concentration decreased strongly up to near $2 \mathrm{mM}$ at $50 \mathrm{~mA} \mathrm{~cm}$ (curve $d$ ). This strong loss in $\mathrm{H}_{2} \mathrm{O}_{2}$ can be related to its destruction from Fenton's reaction (5), also induced by photo-Fenton reaction (23), generating large amounts of ${ }^{\bullet} \mathrm{OH}$ that effectively mineralize mecoprop, as will be discussed below. All these findings indicate that $\mathrm{H}_{2} \mathrm{O}_{2}$ can be produced at high enough rate in a $\mathrm{BDD} / \mathrm{GDE}$ cell to remove relatively concentrated solutions of organic contaminants. 
(a)
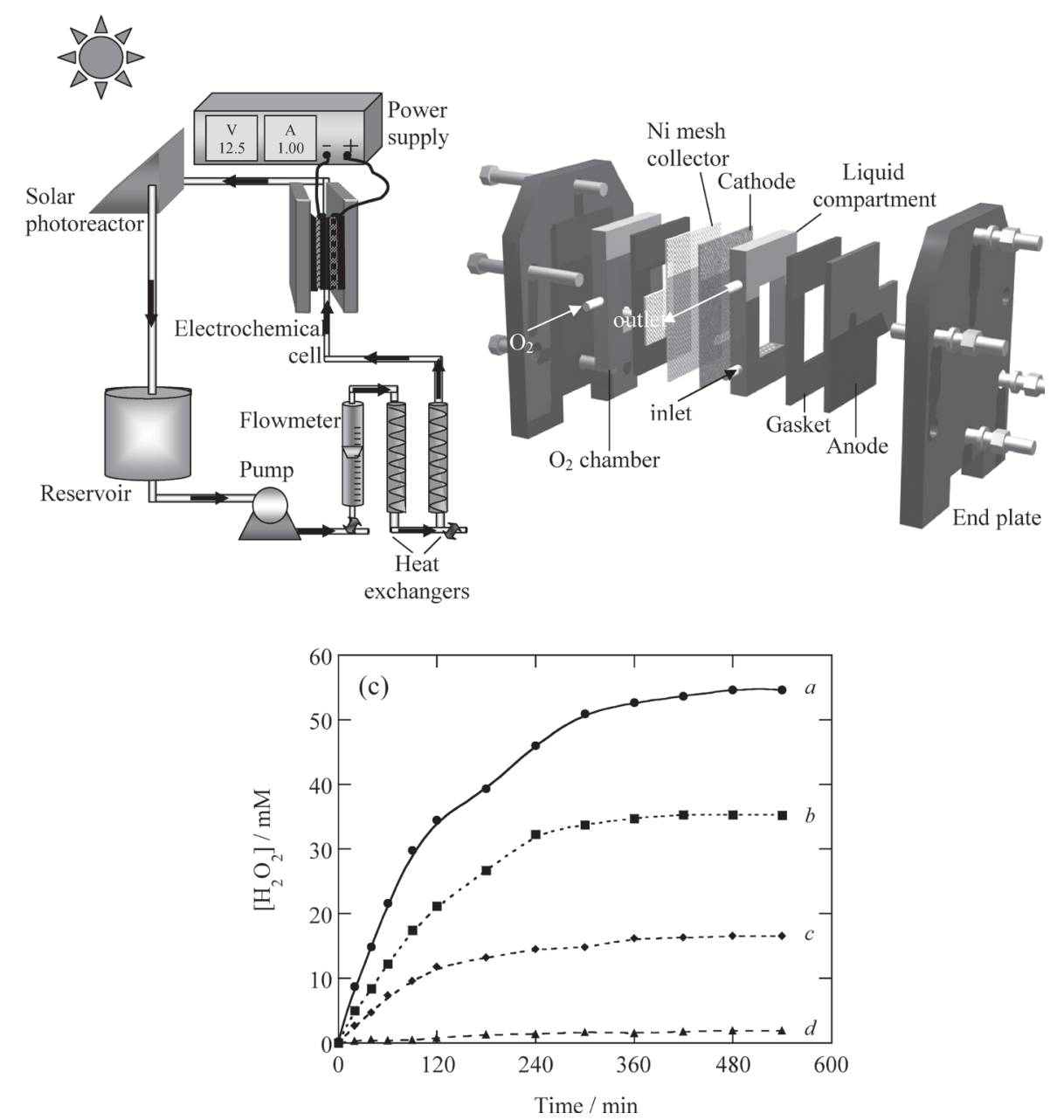

Fig. 1. Schemes of (a) the $2.5 \mathrm{~L}$ pre-pilot plant and (b) the one-compartment filter-press electrochemical reactor with a BDD anode and an $\mathrm{O}_{2}$-diffusion (GDE) cathode, both of 20 $\mathrm{cm}^{2}$ area, used for solar photoelectro-Fenton (SPEF). (c) Concentration of accumulated $\mathrm{H}_{2} \mathrm{O}_{2}$ vs. time during the electrolysis of $2.5 \mathrm{~L}$ of a $0.05 \mathrm{M} \mathrm{Na}_{2} \mathrm{SO}_{4}$ solution at $\mathrm{pH} 3.0$ in the plant at: (a) $150 \mathrm{~mA} \mathrm{~cm}^{-2}$, (b) $100 \mathrm{~mA} \mathrm{~cm}{ }^{-2}$ and (c) $50 \mathrm{~mA} \mathrm{~cm}{ }^{-2}, 25^{\circ} \mathrm{C}$ and liquid flow of $180 \mathrm{~L}$ $\mathrm{h}^{-1}$. In curve $d$, a $100 \mathrm{mg} \mathrm{L}^{-1}$ mecoprop solution with $0.5 \mathrm{mM}$ of $\mathrm{Fe}^{2+}$ was degraded under the same conditions at $50 \mathrm{~mA} \mathrm{~cm}^{-2}$ by SPEF. (Adapted from ref. [34] and [35]).

\section{Mineralization and Energetic Parameters}

The mineralization of organic pollutants in EAOPs is usually monitored from the abatement of its chemical oxygen demand (COD) or its total organic carbon (TOC). When $\mathrm{H}_{2} \mathrm{O}_{2}$ is generated, the measurement of TOC is preferable to avoid the analytical interference of this compound in COD. From these data, the percentage of TOC removal is calculated as follows $[3,8]$ :

$$
\text { TOC removal }(\%)=\frac{\Delta \mathrm{TOC}}{\mathrm{TOC}_{0}} \times 100
$$

where $\triangle \mathrm{TOC}$ is the experimental TOC decay (in $\mathrm{mg} \mathrm{L}^{-1}$ ) at electrolysis time $t$ and $\mathrm{TOC}_{0}$ is the starting value. The mineralization current efficiency (MCE) for an electrolyzed solution at a given time $t$ (in h) is then estimated from Eq. (28) [34, 35]:

$$
\operatorname{MCE}(\%)=\frac{n F V_{\mathrm{s}}(\Delta \mathrm{TOC})}{4.32 \times 10^{7} \mathrm{mIt}} \times 100
$$

where $n$ is the number of electrons exchanged during the mineralization of the checked organic, $F$ is the Faraday constant $\left(96485 \mathrm{C} \mathrm{mol}^{-1}\right), V_{\mathrm{s}}$ is the solution volume (in L), $4.32 \times 10^{7}$ is a conversion factor $\left(=3600 \mathrm{~s} \mathrm{~h}^{-1} \times 12000 \mathrm{mg} \mathrm{C} \mathrm{mol}^{-1}\right), m$ is the number of carbon atoms of the molecule under study and $I$ is the applied current (in A).

The viability of the EAOPs for industrial application is assessed from several energetic parameters. Operating at constant $I$, essential figures-of-merit are the energy consumption per unit volume $(\mathrm{EC})$ and per unit TOC mass $\left(\mathrm{EC}_{\mathrm{TOC}}\right)$, which are calculated from Eqs. (29) and (30), respectively [36, 37]:

$$
\mathrm{EC}\left(\mathrm{kWh} \mathrm{m}^{-3}\right)=\frac{E_{\mathrm{cell}} I t}{V_{\mathrm{s}}}
$$




$$
\mathrm{EC}_{\mathrm{TOC}}\left(\mathrm{kWh} \mathrm{g}^{-1} \mathrm{TOC}\right)=\frac{E_{\mathrm{cell}} I t}{(\Delta \mathrm{TOC}) V_{\mathrm{s}}}
$$

where $E_{\text {cell }}$ is the average potential difference of the cell (in $\mathrm{V})$.

Besides, when colored waters containing a dye are treated, the decay in color is usually determined from the decolorization efficiency or percentage of color removal by Eq. (31) [3]:

$$
\text { Color removal (\%) }=\frac{\mathrm{ABS}_{0}{ }^{\mathrm{M}}-\mathrm{ABS}_{\mathrm{t}}{ }^{\mathrm{M}}}{\mathrm{ABS}_{0}{ }^{\mathrm{M}}} \times 100
$$

where $\mathrm{ABS}_{0}{ }^{\mathrm{M}}$ and $\mathrm{ABS}_{\mathrm{t}}{ }^{\mathrm{M}}$ denote the average absorbances before electrolysis and after an electrolysis time $t$, respectively, at the maximum visible wavelength $\left(\lambda_{\max }\right)$ of the water.

\section{EF Treatment with a BDD Anode of Organic Pollutants}

Our pioneer work on EF with a BDD anode reported the superiority of this method compared to $\mathrm{AO}-\mathrm{H}_{2} \mathrm{O}_{2}$ for the degradation of chlorophenoxy herbicides with a carbon-PTFE $\mathrm{O}_{2}$-fed (GDE) cathode [38]. Other authors have further considered both treatments using different cathodes [18, 39-44]. Several papers have also described the performance of EF alone for the degradation of some recalcitrant compounds $[25,28,45$ 54]. Comparison of the oxidation ability of EF, PEF and SPEF will be discussed below. Figs. $2 a$ and $2 b$ depict the schemes of two typical stirred tank reactors used for such treatments with a BDD anode and $\mathrm{H}_{2} \mathrm{O}_{2}$ electrogeneration $[55,56]$.

The large effectiveness of EF with a BDD anode and a GDE cathode was initially demonstrated using a stirred tank reactor like of Fig. 2a equipped with electrodes of $3 \mathrm{~cm}^{2}$. To do this, solutions containing $100 \mathrm{mg} \mathrm{L}^{-1}$ TOC of the herbicides 4-CPA (4-chlorophenoxyacetic acid), MCPA (4-chloro2-methylphenoxyacetic acid), 2,4-D (2,4-dichlorophenoxyacetic acid) and 2,4,5-T (2,4,5-trichlorophenoxyacetic acid) in 0.05 $\mathrm{M} \mathrm{Na}_{2} \mathrm{SO}_{4}$ of pH 3.0 and $35^{\circ} \mathrm{C}$ were comparatively treated by AO- $\mathrm{H}_{2} \mathrm{O}_{2}$ and EF with $1 \mathrm{mM} \mathrm{Fe}^{2+}$ by applying a current of 100 $\mathrm{mA}$ [38]. Fig. 3a highlights that the TOC of all solutions was removed at similar rate in each EAOP, attaining total mineralization after 6-8 $\mathrm{h}\left(6-8 \mathrm{~A} \mathrm{~h} \mathrm{~L}^{-1}\right)$ of $\mathrm{EF}$, a time slightly shorter than 9-10 h (9-10 $\left.\mathrm{A} \mathrm{h} \mathrm{L} \mathrm{L}^{-1}\right)$ needed for $\mathrm{AO}-\mathrm{H}_{2} \mathrm{O}_{2}$. Although the degradation at the first stages (up to approximately $2 \mathrm{~h}$ ) of $\mathrm{EF}$ was very fast, it needed practically the same time as AO$\mathrm{H}_{2} \mathrm{O}_{2}$ to yield total mineralization. This can be related to the formation of complexes of $\mathrm{Fe}(\mathrm{III})$ with generated carboxylic acids in $\mathrm{EF}$ that are hardly oxidizable with $\operatorname{BDD}\left({ }^{\circ} \mathrm{OH}\right)$ and $\bullet \mathrm{OH}$ generated from reactions (18) and (5), respectively. Fig. $3 \mathrm{~b}$ evidences a very slow decay of all herbicides in AO- $\mathrm{H}_{2} \mathrm{O}_{2}$ up to overall disappearance between $6 \mathrm{~h}$ for 2,4-D and $9 \mathrm{~h}$ for 2,4,5-T, a time slightly shorter than 9-10 $\mathrm{h}$ needed for their total TOC removal (see Fig. 3a), thereby suggesting the destruction of most oxidation products by $\operatorname{BDD}\left({ }^{\bullet} \mathrm{OH}\right)$ at the same rate as generated. In contrast, Fig. 3c shows that all the herbicides were rapidly degraded by $\mathrm{EF}$, disappearing between $12 \mathrm{~min}$ for 2,4$\mathrm{D}$ and $30 \mathrm{~min}$ for MCPA. The quickest decay of herbicides in $\mathrm{EF}$ is then due to their reaction with greater amounts of ${ }^{\bullet} \mathrm{OH}$ (a)

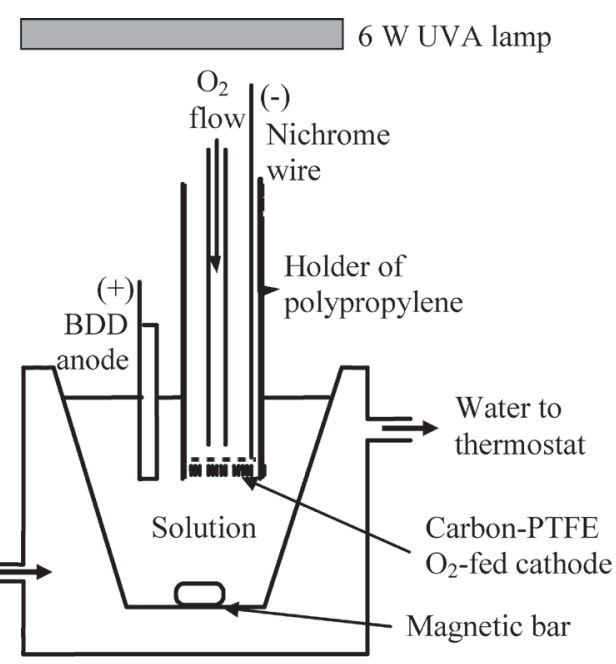

(b)

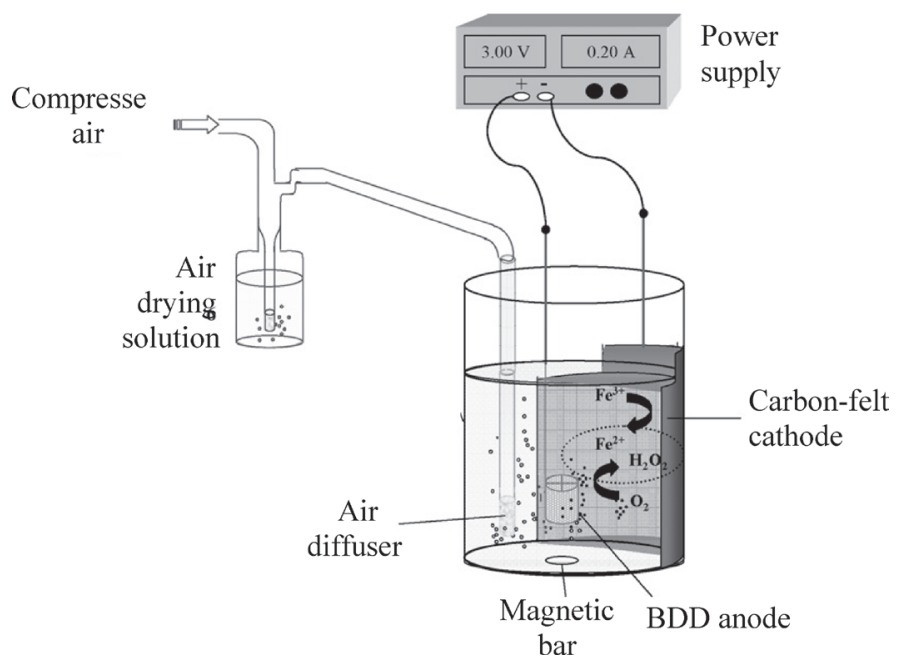

Fig. 2. Schemes of the bench-scaled open and undivided two-electrode cells utilized for the anodic oxidation with electrogenerated $\mathrm{H}_{2} \mathrm{O}_{2}$ $\left(\mathrm{AO}-\mathrm{H}_{2} \mathrm{O}_{2}\right)$ and electro-Fenton $(\mathrm{EF})$ treatments with a BDD anode of organic pollutants. (a) Stirred tank reactor with a carbon-PTFE diffusion cathode directly fed with pure $\mathrm{O}_{2}$, also showing the UVA lamp for the photoelectro-Fenton (PEF) process. (Adapted from ref. [55]). (b) Stirred tank reactor with a carbon-felt cathode and bubbling of compressed air. (Adapted from ref. [56]).

produced from Fenton's reaction (5). The kinetic analysis of the above results given in the insets of Figs. $3 \mathrm{~b}$ and $3 \mathrm{c}$ indicate that all herbicides followed a pseudo-first-order reaction, with an apparent rate constant $\left(k_{1}\right)$ of $5.4 \times 10^{-3}-7.1 \times 10^{-3} \mathrm{~min}^{-1}$ for AO- $\mathrm{H}_{2} \mathrm{O}_{2}$ and as high as $0.12-0.31 \mathrm{~min}^{-1}$ for EF.

Reversed-phase HPLC allowed the detection of the primary phenolic byproduct of each herbicide, that is, 4-chlorophenol for 4-CPA, 4-chloro-o-cresol for MCPA, 2,4-dichlorophenol for 2,4-D and 2,4,5-trichlorophenol for 2,4,5-T. Figs. 4a and $4 \mathrm{~b}$ show that the above phenols were continuously accumulated and destroyed at similar times to those required for the removal 

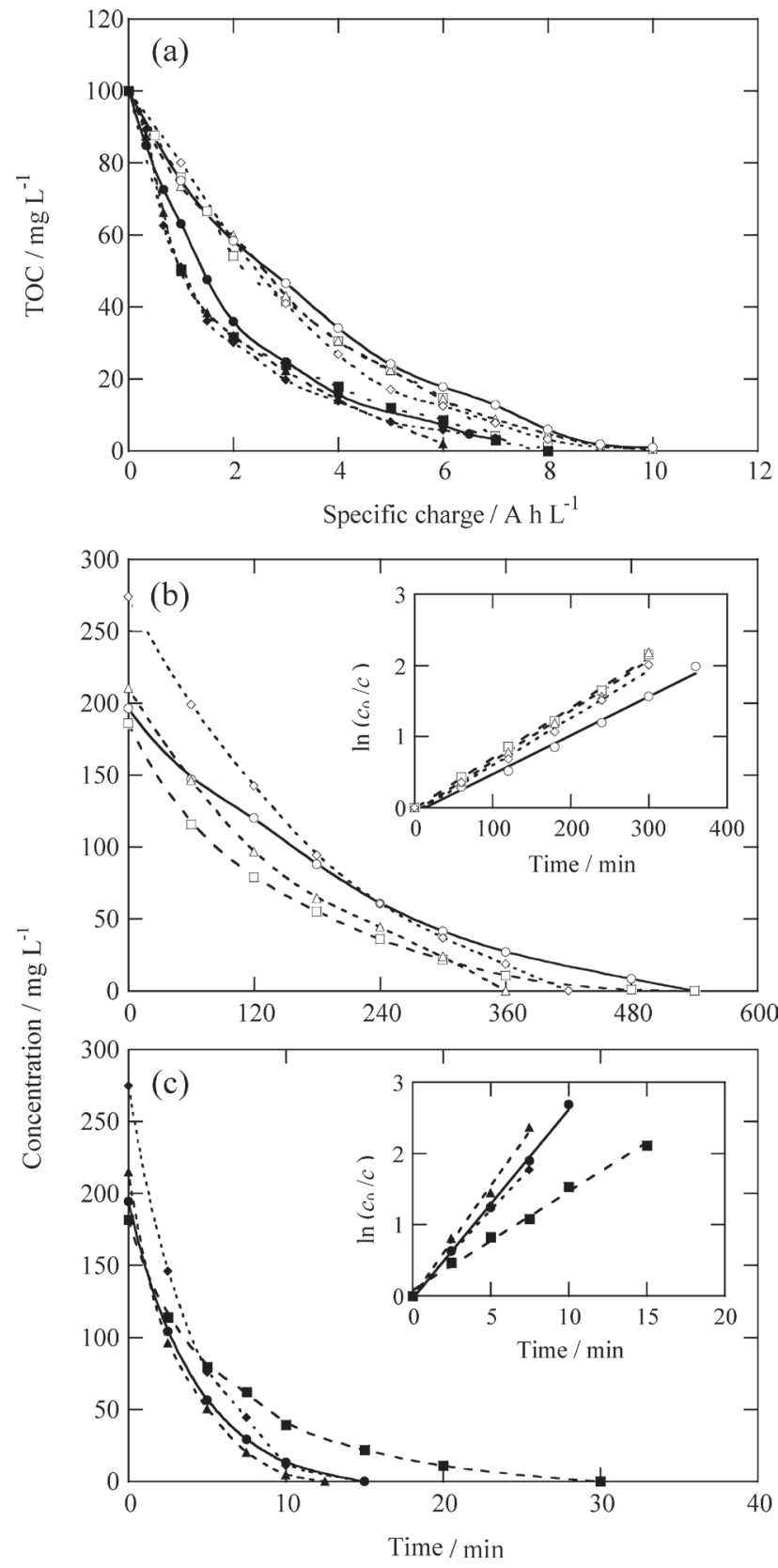

Fig. 3. (a) TOC removal vs. specific charge for the treatment of $100 \mathrm{~mL}$ of: $(\bigcirc, 0) 194 \mathrm{mg} \mathrm{L}^{-1}$ 4-CPA (4-chlorophenoxyacetic acid), $(\square, \square) 200 \mathrm{mg} \mathrm{L}^{-1}$ MCPA (4-chloro-2-methylphenoxyacetic acid), $(\triangle, \boldsymbol{\Delta}) 230 \mathrm{mg} \mathrm{L}^{-1}$ 2,4-D (2,4-dichlorophenoxyacetic acid) and $(\diamond, \diamond) 266 \mathrm{mg} \mathrm{L}^{-1}$ 2,4,5-T (2,4,5-trichlorophenoxyacetic acid) solutions in $0.05 \mathrm{M} \mathrm{Na}_{2} \mathrm{SO}_{4}$ of pH 3.0 using a BDD/GDE cell at $100 \mathrm{~mA}$ and $35^{\circ} \mathrm{C} .(\mathrm{O}, \square, \triangle, \diamond) \mathrm{AO}-\mathrm{H}_{2} \mathrm{O}_{2},(\bullet, \mathbf{\square}, \mathbf{\Delta}, \diamond) \mathrm{EF}$ with $1 \mathrm{mM} \mathrm{Fe}{ }^{2+}$. Concentration decay with electrolysis time for the (b) $\mathrm{AO}-\mathrm{H}_{2} \mathrm{O}_{2}$ and (c) EF treatments. The inset in each plot gives the kinetic analysis assuming a pseudo first-order reaction for each herbicide. (Adapted from ref. [38]).

of the initial herbicides in $\mathrm{AO}-\mathrm{H}_{2} \mathrm{O}_{2}$ and $\mathrm{EF}$, respectively. In both methods phenols were then present in the medium while herbicides are destroyed. A very different behavior was found for oxalic acid, detected as the ultimate carboxylic acid by ionexclusion chromatography. Fig. $4 c$ exemplifies the evolution of
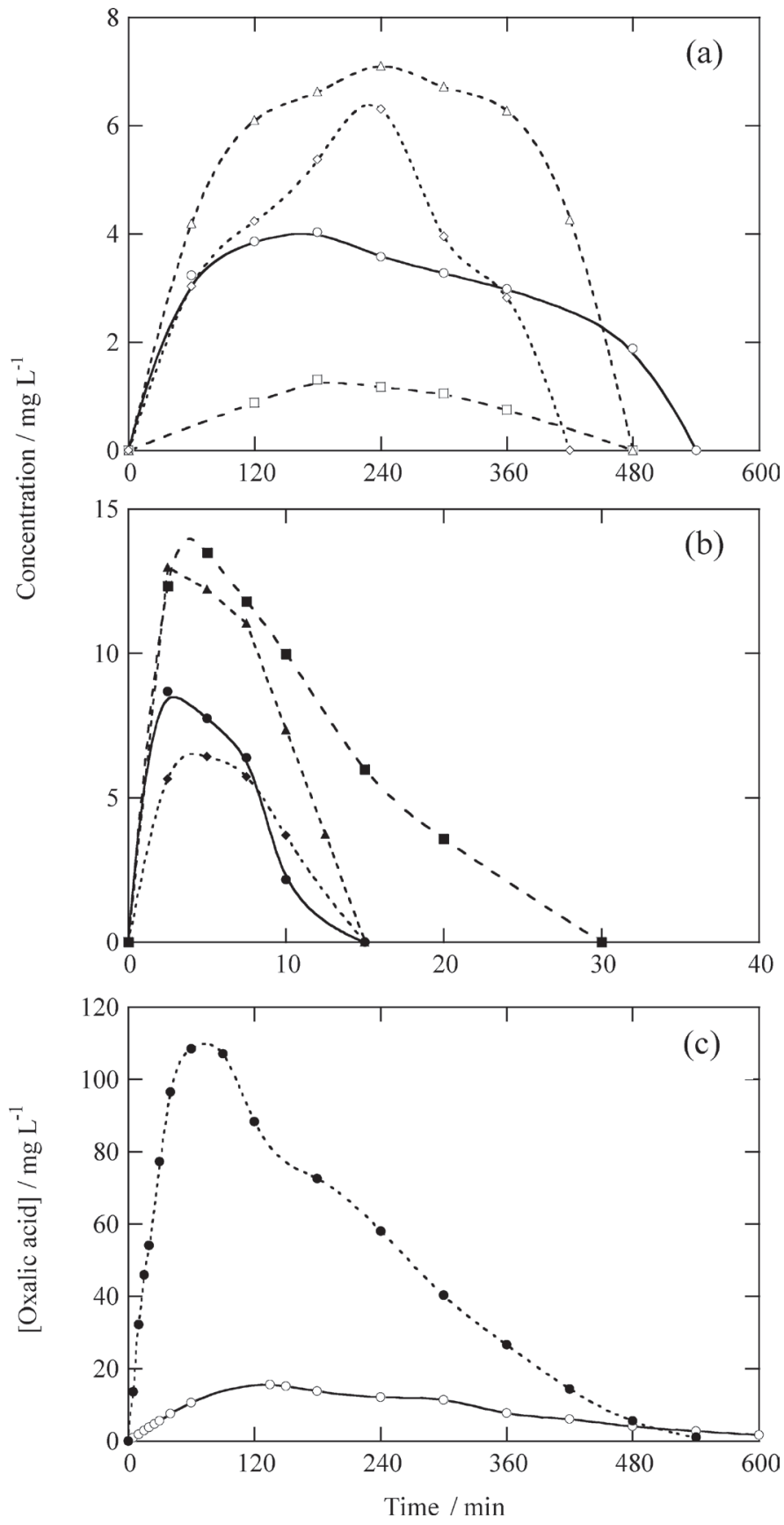

Fig. 4. Time-course of the concentration of primary aromatic products detected during the (a) AO- $\mathrm{H}_{2} \mathrm{O}_{2}$ and (b) EF trials of Fig. 3. $(\mathrm{O}, \bullet)$ 4-Chlorophenol from 4-CPA, $(\square, \boldsymbol{n})$ 4-chloro-o-cresol from MCPA, $(\triangle, \mathbf{\Delta})$ 2,4-dichlorophenol from 2,4-D and $(\diamond, \diamond)$ 2,4,5-trichlorophenol from 2,4,5-T. (c) Evolution of oxalic acid concentration during the (O) AO- $\mathrm{H}_{2} \mathrm{O}_{2}$ and (-) EF treatments of $194 \mathrm{mg} \mathrm{L}^{-1}$ 4-CPA solutions under the conditions of Fig. 3. (Adapted from ref. [38]).

this acid in the case of 4-CPA degradation. As can be seen, its concentration in $\mathrm{AO}-\mathrm{H}_{2} \mathrm{O}_{2}$ only rose to $16 \mathrm{mg} \mathrm{L}^{-1}$ and decayed slowly up to its disappearance at $10 \mathrm{~h}$, just when the solution TOC (see Fig. 3a) was completely removed. In EF this acid was accumulated in much larger extent because of the rapid degradation of aromatics and precedent carboxylic acids, then being slowly transformed into $\mathrm{CO}_{2}$ in 8 h, i.e., the same time 
as required for total 4-CPA mineralization (see Fig. 3a). This was ascribed to the fact that $\mathrm{Fe}$ (III)-oxalato complexes can only be attacked by $\mathrm{BDD}\left({ }^{\circ} \mathrm{OH}\right)$ since they are stable in $\mathrm{EF}$ with a $\mathrm{Pt}$ anode. The very slow destruction of such complexes on BDD then explains the difficulty of achieving total decontamination of herbicides by EF.

The superiority of EF over $\mathrm{AO}-\mathrm{H}_{2} \mathrm{O}_{2}$ with a BDD anode has also been reported by other authors. Thus, Rodríguez De León et al. [40] used a cylindrical cell equipped with a $2 \mathrm{~cm}^{2}$ BDD anode and a $4 \mathrm{~cm}^{2}$ BDD cathode and filled with $40 \mathrm{~mL}$ of an air-saturated solution in $0.05 \mathrm{M} \mathrm{Na}_{2} \mathrm{SO}_{4}$ of $\mathrm{pH} 3.0$ to comparatively decolorize and degrade $60 \mathrm{mg} \mathrm{L}^{-1}$ of the dyes Acid Yellow 36 and Methyl Orange. The decolorization processes always followed a pseudo-first-order reaction with an apparent rate constant $\left(k_{\text {app }}\right)$ that increased largely in EF compared to AO- $\mathrm{H}_{2} \mathrm{O}_{2}$ when up to $0.3 \mathrm{mM} \mathrm{Fe}^{2+}$ was added to the solution, as a consequence of the additional oxidation with ${ }^{\circ} \mathrm{OH}$ formed in the bulk from Fenton's reaction (5). Abdessalem et al. [41] corroborated again the enhancement of organic degradation when ${ }^{\circ} \mathrm{OH}$ at the BDD surface and in the medium are simultaneously produced during the $\mathrm{EF}$ process with $\mathrm{Fe}^{3+}$ as catalyst. Air-saturated solutions of $250 \mathrm{~mL}$ with $0.125 \mathrm{mM}$ of each of three pesticides chlortoluron, carbofuran and bentazone in 0.05 $\mathrm{M} \mathrm{Na}_{2} \mathrm{SO}_{4}$ of $\mathrm{pH} 3.0$ were treated in a stirred tank reactor like of Fig. 2b equipped with a $14 \mathrm{~cm}^{2} \mathrm{BDD}$ anode and a $60 \mathrm{~cm}^{2}$ $\mathrm{CF}$ cathode. Under these conditions and operating at $300 \mathrm{~mA}$, the three pesticides disappeared completely in $90-150 \mathrm{~min}$ in AO- $\mathrm{H}_{2} \mathrm{O}_{2}$, but only in 70-90 min in EF, always obeying a pseudo-first-order kinetics as detected by reversed-phase HPLC. Similarly, 90\% TOC removal was achieved in $240 \mathrm{~min}$ of AO$\mathrm{H}_{2} \mathrm{O}_{2}$, which was substantially reduced to $120 \mathrm{~min}$ in EF. At longer time, however, the reactivity of the remaining organic matter, mainly carboxylic acids, with hydroxyl radicals was so strongly inhibited that TOC was only reduced by $97-98 \%$ after $4 \mathrm{~h}$ of both treatments. Ion chromatography of degraded solutions revealed the total conversion of the initial $\mathrm{Cl}, \mathrm{N}$ and $\mathrm{S}$ of the pesticides into $\mathrm{Cl}^{-}, \mathrm{NH}_{4}{ }^{+}$and $\mathrm{SO}_{4}{ }^{2-}$ ions, respectively, although $\mathrm{Cl}^{-}$ion was slowly oxidized to $\mathrm{Cl}_{2}$.

The large effectiveness of the BDD anode has also been described for the destruction of the pesticide atrazine (2-chloro-4-ethylamino-6-isopropylamino-1,3,5-triazine), since this compound can only be transformed into cyanuric acid $(2,4,6-$ trihydroxy-1,3,5-triazine) by chemical AOPs with in situ ${ }^{\bullet} \mathrm{OH}$ production in the bulk. The study performed by Oturan et al. [43] demonstrated that using a stirred tank reactor like of Fig. $2 \mathrm{~b}$ with a $25 \mathrm{~cm}^{2} \mathrm{BDD}$ anode and applying a constant current of $1 \mathrm{~A}$, the TOC of a $0.1 \mathrm{mM}$ atrazine solution in $0.1 \mathrm{M} \mathrm{Na}_{2} \mathrm{SO}_{4}$ was reduced by $93 \%$ at $\mathrm{pH} 6.9$ using $\mathrm{AO}-\mathrm{H}_{2} \mathrm{O}_{2}$ and by $97 \%$ at $\mathrm{pH} 3.0$ using EF with $0.1 \mathrm{mM} \mathrm{Fe}^{3+}$ as catalyst. In contrast, when a Pt anode was utilized in the EF process, only $83 \%$ of TOC removal was found under similar conditions. These results evidence that almost all the byproducts of atrazine, including cyanuric acid, can be destroyed by $\mathrm{BDD}\left({ }^{\circ} \mathrm{OH}\right)$ but not by $\mathrm{Pt}\left({ }^{\bullet} \mathrm{OH}\right)$ formed from reaction (18), while the generation of -OH from Fenton's reaction (5) accelerates slightly the mineralization process.
It is also noteworthy the work of Montanaro et al. [39], who proposed the combination of the $\mathrm{AO}$ and $\mathrm{EF}$ processes to reduce the phosphorus content of an effluent from the manufacture of phosphorus-based flame retardants. A divided BDD/ GDE cell with an anionic membrane was used. The method consisted in the AO treatment with a BDD anode of $100 \mathrm{~mL}$ of a fresh solution in the anolyte of the cell, followed by EF oxidation of this pretreated solution in the catholyte by ${ }^{\circ} \mathrm{OH}$ produced from Fenton's reaction (5). The anionic membrane allowed the passage of $\mathrm{OH}^{-}$ions from the cathodic to the anodic compartment to maintain the catholyte $\mathrm{pH}$ close to 1.5 , thereby avoiding iron precipitation. A sequential running saved charge and time by using both anode and cathode performances in parallel, only needing $240 \mathrm{~min}$ at $10 \mathrm{~mA} \mathrm{~cm}^{-2}$ to decrease the phosphorus content below the limits needed.

The Peralta-Hernández's group has optimized the decolorization process of the azo dye Acid Yellow 36 by EF in a stirred tank reactor with a $2 \mathrm{~cm}^{2}$ BDD anode and cathode by means of response surface methodology (RSM) [25, 48]. Solutions of $100 \mathrm{~mL}$ containing 60,70 and $80 \mathrm{mg} \mathrm{L}^{-1}$ of the dye were comparatively degraded in $0.05 \mathrm{M} \mathrm{Na}_{2} \mathrm{SO}_{4}$ as background electrolyte at initial $\mathrm{pH} 3.0$ by applying a constant current density of 8,15 and $23 \mathrm{~mA} \mathrm{~cm}^{-2}$ after addition of $0.1,0.2$ and $0.3 \mathrm{mM}$ $\mathrm{Fe}^{2+}$. With these results, RSM was able to predict the optimal operating conditions to achieve $96 \%$ color removal with complete dye removal, which were $80 \mathrm{mg} \mathrm{L}^{-1}$ of the dye, $15 \mathrm{~mA}$ $\mathrm{cm}^{-2}, 0.3 \mathrm{mM} \mathrm{Fe} \mathrm{F}^{2+}$ and 50 min of electrolysis time. This was confirmed with UV-vis and HPLC assessments during the EF treatment with BDD. More recently, this group has scaled-up the $\mathrm{EF}$ process to a recirculation pre-pilot plant of $3 \mathrm{~L}$, similar to that of Fig. 1a but without photoreactor [53]. The BDD/BDD reactor contained electrodes of $64 \mathrm{~cm}^{2}$ area and solutions of 100,150 and $200 \mathrm{mg} \mathrm{L}^{-1}$ Methyl Orange with $0.05 \mathrm{M} \mathrm{Na}_{2} \mathrm{SO}_{4}$ and $0.3 \mathrm{mM} \mathrm{Fe}^{2+}$ of $\mathrm{pH} 3.0$ were decolorized at $7.8,15$ and 31 $\mathrm{mA} \mathrm{cm}{ }^{-2}$. After 60 min of electrolysis, the higher color removal of $70 \%$ was reached for $200 \mathrm{mg} \mathrm{L}^{-1}$ of Methyl Orange at 31 $\mathrm{mA} \mathrm{cm}{ }^{-2}$ due to the more effective degradation by ${ }^{\bullet} \mathrm{OH}$ formed at the BDD anode and from Fenton's reaction (5). Ascorbic, benzoic, citric, maleic and oxalic acids were identified as intermediates by HPLC.

In collaboration between our group and Oturan's group, the antimicrobials chlorophene, triclocarban and triclosan were comparatively degraded by four EF systems consisting of Pt/ GDE, BDD/GDE, Pt/CF and BDD/CF cells with $\mathrm{Fe}^{3+}$ as the catalyst $[28,45]$. In the cells with the GDE cathode (like of Fig. 2a), the pollutant decay was enhanced at greater $\mathrm{Fe}^{3+}$ content because this promoted quicker $\mathrm{Fe}^{2+}$ regeneration at the cathode with larger ${ }^{\circ} \mathrm{OH}$ production from Fenton's reaction (5). In contrast, when the CF cathode was used (cell of Fig. 2b), $\mathrm{Fe}^{2+}$ ion was largely accumulated as a result of the quick $\mathrm{Fe}^{3+}$ cathodic reaction (16) and so, only $0.2 \mathrm{mM} \mathrm{Fe}^{3+}$ was required to obtain the maximum ${ }^{\circ} \mathrm{OH}$ generation rate. Under these conditions, absolute rate constants of $1.00 \times 10^{10}$ and $5.49 \times 10^{9} \mathrm{M}^{-1}$ $\mathrm{s}^{-1}$ were obtained for the decay of chlorophene and triclosan, respectively. A poor mineralization degree was found for the $\mathrm{Pt} / \mathrm{GDE}$ cell because of the difficult oxidation of final Fe(III)- 
oxalate complexes with ${ }^{\bullet} \mathrm{OH}$. These species were completely destroyed using the BDD/GDE cell at high current thanks to the great amount of reactive $\mathrm{BDD}\left({ }^{\circ} \mathrm{OH}\right)$ generated. Total mineralization was also achieved in both CF cells owing to the efficient oxidation of $\mathrm{Fe}(\mathrm{II})$-oxalate complexes with ${ }^{\circ} \mathrm{OH}$ in the bulk. The higher oxidation ability was attained for the BDD/ $\mathrm{CF}$ cell by the extra destruction of Fe(II)-oxalate complexes with $\operatorname{BDD}\left({ }^{\circ} \mathrm{OH}\right)$. Primary oxidation products like 2,4-dichlorophenol, 4-chlorocatechol, chlorohydroquinone and chloro- $p$ benzoquinone were identified for triclosan, whereas urea, hydroquinone, chlorohydroquinone, 1-chloro-4-nitrobenzene and 1,2-dichloro-4-nitrobenzene were found for triclocarban.

Our group has later considered the EF treatment of chlorinated aliphatic hydrocarbons such as 1,2-dichloroethane (DCA) and 1,1,2,2-tetrachloroethane (TCA) using a stirred tank reactor like of Fig. 2a [49]. Bulk electrolyses of $130 \mathrm{~mL}$ of $4 \mathrm{mM}$ of both compounds in $0.035 \mathrm{M} \mathrm{Na}_{2} \mathrm{SO}_{4}$ with $0.5 \mathrm{mM} \mathrm{Fe}^{2+}$ at $\mathrm{pH} 3.0,300 \mathrm{~mA}$ and $10{ }^{\circ} \mathrm{C}$ yielded almost total mineralization in 420 min when a BDD/GDE cell was tested. Poorer degradation was obtained in comparative $\mathrm{AO}-\mathrm{H}_{2} \mathrm{O}_{2}$ process or using a Pt anode in EF. Chloroacetic and dichloroacetic acids were the major by-products formed during the degradation of DCA and TCA, respectively. Acetic, oxalic and formic acids were also produced. Chlorine was released as $\mathrm{Cl}^{-}$ion, being further oxidized to $\mathrm{ClO}_{3}{ }^{-}$ion and, mostly, to $\mathrm{ClO}_{4}{ }^{-}$ion due to the action of the largely generated $\operatorname{BDD}\left({ }^{\bullet} \mathrm{OH}\right)$ and ${ }^{\bullet} \mathrm{OH}$. Another study was carried out over the comparative degradation of the monoazo Acid Orange 7, diazo Acid Red 151 and triazo Direct Blue 71 by EF with a BDD/GDE cell [50]. The initial decolorization rate decreased with increasing initial azo bonds concentration due to the oxidation of more organic matter with similar amounts of hydroxyl radicals. Interestingly, this parameter lowered as the number of azo bonds in the molecule increased owing to their smaller reactivity with hydroxyl radicals. Reversed-phase HPLC revealed the total removal of all azo dyes following a pseudo first-order kinetics with rate constants showing the same trends as those predicted by initial decolorization rates. However, the decolorization process was slower as a consequence of the parallel destruction of colored conjugated intermediates formed during the EF treatment.

On the other hand, the Oturan's group has reported more fundamental information on the performance of $\mathrm{EF}$ with $\mathrm{BDD}$ using a cell like of Fig. $2 b$ for the effective destruction of several organic pollutants like the dye Acid Orange 7 [46], the herbicide propham [47] and the antibiotic sulfachloropyridazine [51] in aqueous solutions, as well as the analgesic/antiinflammatory ibuprofen in acetonitrile/water medium [54]. In these works, it is noticeable the determination of the absolute rate constant for the reaction of ${ }^{\bullet} \mathrm{OH}$ with Acid Orange $7\left(k_{2}=\right.$ $\left.1.1 \times 10^{10} \mathrm{M}^{-1} \mathrm{~s}^{-1}\right)$ and sulfachloropyridazine $\left(k_{2}=1.6 \times 10^{9} \mathrm{M}^{-1}\right.$ $\mathrm{s}^{-1}$ ) using the competition kinetic method. Besides, intermediates and released inorganic ions were detected by GC-MS and HPLC. This allowed for each contaminant the proposal of a degradative route to explain its mineralization under the action of $\mathrm{BDD}\left({ }^{\bullet} \mathrm{OH}\right)$ and ${ }^{\bullet} \mathrm{OH}$ generated from reaction (18) and Fenton's reaction (5), respectively.

\section{PEF Degradation with a BDD Anode of Organic Contaminants}

The former work of our group on the PEF process with a BDD anode was focused to show its performance to destroy a toxic aromatic dye as Indigo Carmine (C.I. Acid Blue 64). The characteristics of the EF and PEF treatments of $100 \mathrm{~mL}$ of aqueous solutions containing $220 \mathrm{mg} \mathrm{L}^{-1}$ of this dye and $\mathrm{Fe}^{2+}$ and/or $\mathrm{Cu}^{2+}$ as catalysts at $\mathrm{pH} 3.0$ with $\mathrm{Pt} / \mathrm{GDE}$ and BDD/ GDE cells like of Fig. 2a, with electrodes of $3 \mathrm{~cm}^{2}$ area, at $100 \mathrm{~mA}$ and $35.0^{\circ} \mathrm{C}$ were then studied [57]. While EF with Pt and $1.0 \mathrm{mM} \mathrm{Fe}^{2+}$ gave poor mineralization, only attaining $49 \%$ TOC removal in $540 \mathrm{~min}$, EF with BDD promoted $91 \%$ TOC reduction at the same time, reaching total mineralization with loss of $\mathrm{NH}_{4}{ }^{+}$ion in $780 \mathrm{~min}$. This evidences again the much higher oxidation ability of $\operatorname{BDD}\left({ }^{\bullet} \mathrm{OH}\right)$ compared with $\mathrm{Pt}\left({ }^{\circ} \mathrm{OH}\right)$ to remove organic matter. Indigo Carmine obeyed a pseudo-zero-order decay kinetics, as determined by HPLC, and disappeared at the same time as its aromatic derivatives isatin 5sulphonic acid, indigo and isatin, mainly by reaction with ${ }^{\circ} \mathrm{OH}$ produced from Fenton's reaction (5). The most persistent byproducts were oxalic and oxamic acids, present in the medium as $\mathrm{Fe}(\mathrm{III})$-oxalate and $\mathrm{Fe}(\mathrm{III})$-oxamate complexes. Figs. 5a and $\mathrm{b}$ evidence that both complexes were poorly attacked with ${ }^{\circ} \mathrm{OH}$ and $\mathrm{Pt}\left({ }^{\circ} \mathrm{OH}\right)$ in $\mathrm{EF}$ with $\mathrm{Pt}$, but they were completely destroyed with $\mathrm{BDD}\left({ }^{\circ} \mathrm{OH}\right)$ in $\mathrm{EF}$ with $\mathrm{BDD}$, in agreement with the greater oxidation power of the latter radical. In PEF with Pt under a $6 \mathrm{~W}$ UVA light, TOC was reduced by $84 \%$ in $540 \mathrm{~min}$ and Fe(III)-oxalate complexes disappeared in $480 \mathrm{~min}$ (see Fig. 5a), but $\mathrm{Fe}(\mathrm{III})$-oxamate complexes attained a steady concentration (see Fig. 5b). Consequently, the superiority of PEF compared to $\mathrm{EF}$ was related to the quick photolysis of $\mathrm{Fe}$ (III)-oxalate complexes from reaction (25). $\mathrm{Cu}^{2+}$ was then added as co-catalyst trying to produce additional quantity of ${ }^{\bullet} \mathrm{OH}$. It has been proposed that $\mathrm{Cu}^{2+}$ can be reduced to $\mathrm{Cu}^{+}$with $\mathrm{HO}_{2}{ }^{\bullet}$ from reaction (32) and then, $\mathrm{Cu}^{2+}$ can be regenerated either from the Fentonlike reaction (33) yielding more ${ }^{\circ} \mathrm{OH}$ or from reaction (34) producing more $\mathrm{Fe}^{2+}$ to enhance Fenton's reaction (5) $[58,59]$ :

$$
\begin{gathered}
\mathrm{Cu}^{2+}+\mathrm{HO}_{2}{ }^{\bullet} \rightarrow \mathrm{Cu}^{+}+\mathrm{O}_{2}+\mathrm{H}^{+} \\
\mathrm{Cu}^{+}+\mathrm{H}_{2} \mathrm{O}_{2} \rightarrow \mathrm{Cu}^{2+}+\cdot \mathrm{OH}+\mathrm{OH}^{-} \\
\mathrm{Cu}^{+}+\mathrm{Fe}^{3+} \rightarrow \mathrm{Cu}^{2+}+\mathrm{Fe}^{2+}
\end{gathered}
$$

Surprisingly, PEF with Pt and $1.0 \mathrm{mM} \mathrm{Fe}{ }^{2+}+0.25 \mathrm{mM}$ $\mathrm{Cu}^{2+}$ promoted almost total mineralization $(>97 \%$ TOC removal) in 450 min due to a faster and total destruction of both oxalic and oxamic acids (see Figs. 5a and b). The synergistic effect of $\mathrm{Fe}^{2+}$ and $\mathrm{Cu}^{2+}$ was explained by: (i) the photolysis of $\mathrm{Fe}(\mathrm{III})$-oxalate complexes and (ii) the simultaneous reaction of competitively formed $\mathrm{Cu}$ (II)-oxalate and $\mathrm{Cu}$ (II)-oxamate complexes with ${ }^{\bullet} \mathrm{OH}$ in the bulk. The proposed reaction pathways for the processes involved in the mineralization of oxalic and oxamic acids in the presence of both catalysts are shown in Figs. $5 \mathrm{c}$ and d, respectively. 


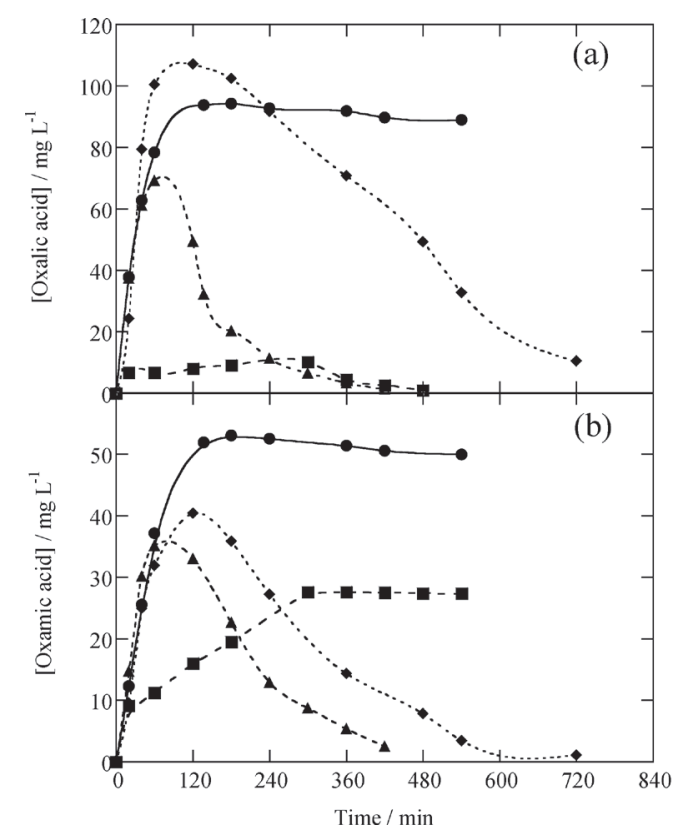

(c)

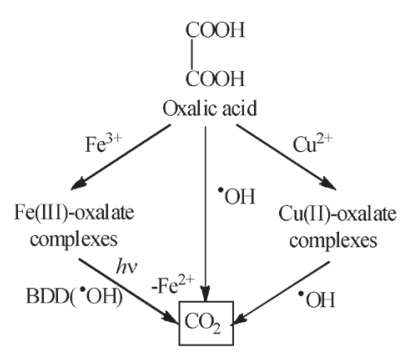

(d)

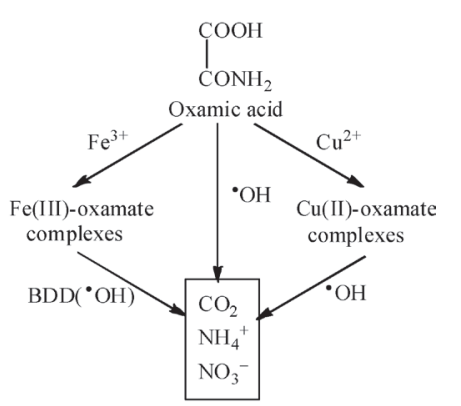

Fig. 5. Evolution of the concentration of (a) oxalic and (b) oxamic acids during the degradation of $100 \mathrm{~mL}$ of $220 \mathrm{mg} \mathrm{L}^{-1}$ Indigo Carmine solutions in $0.05 \mathrm{M} \mathrm{Na}_{2} \mathrm{SO}_{4}$ at $\mathrm{pH} 3.0,33 \mathrm{~mA} \mathrm{~cm}^{-2}$ and 35.0 ${ }^{\circ} \mathrm{C}$ using a Pt/GDE or BDD/GDE cell with $3 \mathrm{~cm}^{2}$ electrodes. Process: (-) EF with Pt and $1.0 \mathrm{mM}$ $\mathrm{Fe}^{2+}$, (ם) PEF with Pt, $1.0 \mathrm{mM} \mathrm{Fe}{ }^{2+}$ under $6 \mathrm{~W}$ UVA light, (•) EF with BDD and $1.0 \mathrm{mM} \mathrm{Fe}{ }^{2+}$ and $(\boldsymbol{\Delta})$ PEF with $\mathrm{Pt}$ and $1.0 \mathrm{mM} \mathrm{Fe}{ }^{2+}+0.25 \mathrm{mM} \mathrm{Cu}^{2+}$. Proposed pathways for the mineralization of (c) oxalic and (d) oxamic acids. (Adapted from ref. [57]).

The action of UVA light in the PEF process was further clarified by treating $100 \mathrm{~mL}$ of a $200 \mathrm{mg} \mathrm{L}^{-1}$ Direct Yellow 4 solution in $0.05 \mathrm{M} \mathrm{Na}_{2} \mathrm{SO}_{4}$ with $0.5 \mathrm{mM} \mathrm{Fe}^{2+}$ at $\mathrm{pH} 3.0,33.3$ $\mathrm{mA} \mathrm{cm}{ }^{-2}$ and $35{ }^{\circ} \mathrm{C}$ in a similar BDD/GDE cell [60]. Fig. 6a depicts that the dye was not photodecomposed under a $6 \mathrm{~W}$ UVA irradiation, while the solution TOC was reduced by $84 \%$ and $97 \%$ after $360 \mathrm{~min}$ of EF and PEF, respectively. When the EF process was made for $60 \mathrm{~min}, 31 \%$ TOC was removed, but the Fenton's reagent remaining in the solution had oxidation ability enough to reduce the TOC by $45 \%$ up to $180 \mathrm{~min}$, thus demonstrating the oxidation role of ${ }^{\bullet} \mathrm{OH}$ formed from Fenton's reaction (5) in EF. In contrast, if the solution treated during 60 min in PEF was subsequently submitted to UVA irradiation, TOC abatement gradually increased up to $81 \%$, whereas if the UVA light was applied after $120 \mathrm{~min}$ of EF, 97\% TOC decay, equal to obtained in PEF, was found (see Fig. 6b). This is a very interesting finding, because it clearly shows that the photolytic action of UVA light, also involving the photodegradation of Fe(III)-oxalate complexes, acts pre-eminently at long electrolysis time of the PEF method. On the other hand, Almeida et al. [61] showed a quicker and total decolorization by PEF compared to EF for $100 \mathrm{~mL}$ of a $244 \mathrm{mg} \mathrm{L}^{-1}$ Acid Red 29 solution in $0.05 \mathrm{M} \mathrm{Na}_{2} \mathrm{SO}_{4}$ under optimum conditions of $0.5 \mathrm{mM} \mathrm{Fe}^{2+}$ and $\mathrm{pH} 3.0$ at $35^{\circ} \mathrm{C}$ also using a stirred BDD/GDE tank reactor with $3 \mathrm{~cm}^{2}$ electrode area. The dye followed a pseudo-first-order decay with similar rate for EF and PEF. Since it disappeared much more rapidly than solution color, it was proposed that the decolorization process involved the destruction of colored conjugated products with $\lambda_{\max }$ similar to that of Acid Red 29, which was enhanced in PEF by the production of more ${ }^{\bullet} \mathrm{OH}$ from photo-Fenton reaction (23). Almost total mineralization was found for PEF, whereas poorer degradation was achieved by EF. In the PEF process, Fe(III)-oxalate complexes were efficiently photolyzed, but tartronic and oxamic acids were the most persistent byproducts because of the larger stability of their Fe(III) complexes. The initial $\mathrm{N}$ of the azo dye yielded $\mathrm{NO}_{3}{ }^{-}$ion, along with a smaller proportion of $\mathrm{NH}_{4}{ }^{+}$ion.

The great oxidation ability of PEF with BDD was also confirmed from the degradation of other chlorophenoxy herbicide such as 2,4-dichlorophenoxypropionic acid (2,4-DP) in a BDD/GDE cell [21]. The EF and PEF processes with $1 \mathrm{mM}$ $\mathrm{Fe}^{2+}$ led to complete mineralization of $100 \mathrm{~mL}$ of $217 \mathrm{mg} \mathrm{L}{ }^{-1}$ 2,4-DP solutions at $\mathrm{pH} 3.0300 \mathrm{~mA}$ and $35^{\circ} \mathrm{C}$, with overall loss of chloride ion. Nevertheless, the UVA light in PEF had little effect on the degradation rate of pollutants compared with the fast oxidation produced by $\operatorname{BDD}\left({ }^{\bullet} \mathrm{OH}\right)$ and ${ }^{\bullet} \mathrm{OH}$. As expected, the comparative procedures with Pt promoted slower decontamination because of the lower oxidizing power of this anode.

A further research of our group was devoted to the degradation of several s-triazinic herbicides such as atrazine [62], desmetryne (2-isopropylamino-4-methylamino-6-methylthio1,3,5-triazine) [63] and cyanacine (2-(4-chloro-6-ethylamino1,3,5-triazin-2-ylamino)-2-methylpropiononitrile) [64], which are difficultly oxidizable by AOPs because, as explained above, they are transformed into cyanuric acid that cannot be destroyed by ${ }^{\bullet} \mathrm{OH}$. The treatment of the three s-triazines with a stirred $\mathrm{BDD} / \mathrm{GDE}$ tank reactor demonstrated that an almost total min- 


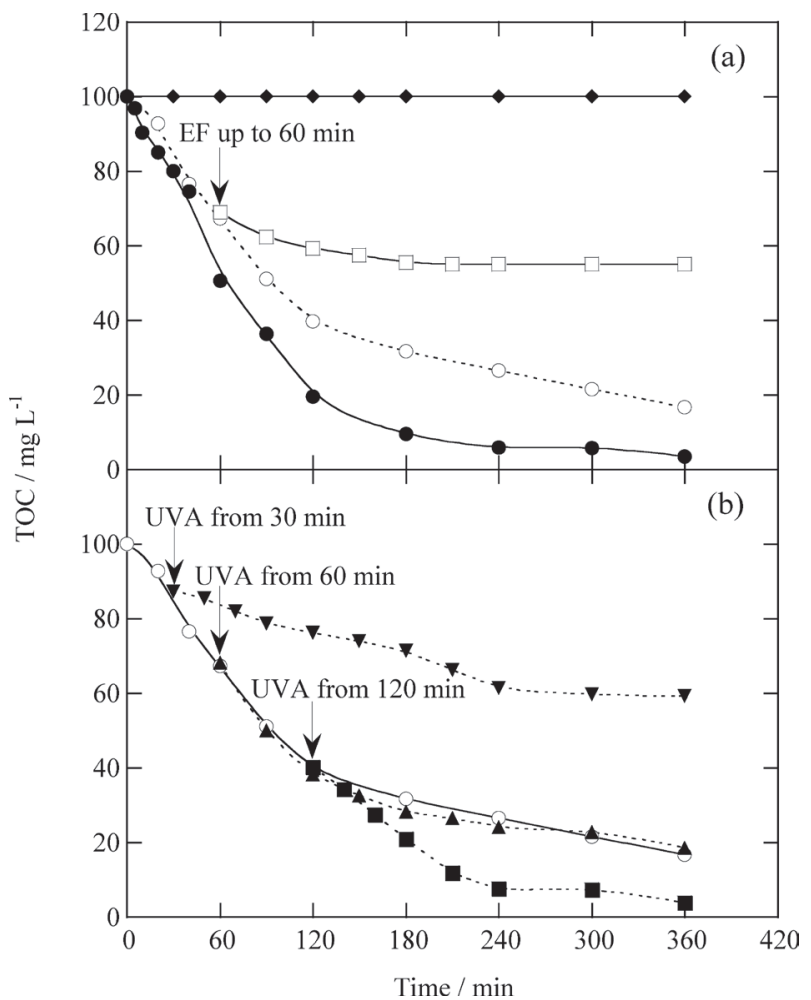

Fig. 6. TOC abatement vs electrolysis time for $100 \mathrm{~mL}$ of a $200 \mathrm{mg}$ $\mathrm{L}^{-1}$ Direct Yellow 4 solution in $0.05 \mathrm{M} \mathrm{Na}_{2} \mathrm{SO}_{4}$ with $0.5 \mathrm{mM} \mathrm{Fe}{ }^{2+}$ at $\mathrm{pH} 3.0,33.3 \mathrm{~mA} \mathrm{~cm}{ }^{-2}$ and $35^{\circ} \mathrm{C}$ using a BDD/GDE cell. In plot $(a),(\diamond) 6 \mathrm{~W}$ UVA irradiation, $(\bigcirc)$ EF and $(\bullet)$ PEF with $6 \mathrm{~W}$ UVA light. ( $\square$ ) EF process up to $60 \mathrm{~min}$, whereupon the resulting solution remained without any treatment. In plot $(b),(O)$ EF process and photo-assisted EF degradation where only UVA irradiation was applied to the solution after: $(\boldsymbol{\nabla}) 30 \mathrm{~min},(\boldsymbol{\Delta}) 60 \mathrm{~min}$ and $(\boldsymbol{\square}) 120 \mathrm{~min}$ of electrolysis. (Adapted from ref. [60]).

eralization was always achieved by $\mathrm{AO}-\mathrm{H}_{2} \mathrm{O}_{2}$, EF and PEF since cyanuric acid can be removed by generated $\operatorname{BDD}\left({ }^{\circ} \mathrm{OH}\right)$. This behavior can be observed in Fig. 7a for $30 \mathrm{mg} \mathrm{L}^{-1}$ atrazine, where $90-92 \%$ mineralization was attained in $\mathrm{AO}-\mathrm{H}_{2} \mathrm{O}_{2}$ and PEF after $540 \mathrm{~min}$ of electrolysis at $100 \mathrm{~mA}$ and $360 \mathrm{~min}$ at 300 and $450 \mathrm{~mA}$. The increase in current caused the spent of more specific charge, also reflected in the gradual fall in MCE, shown in Fig. 7b, suggesting a higher increase in rate of waste reactions (19)-(22). The low increase in TOC removal for PEF compared to $\mathrm{AO}-\mathrm{H}_{2} \mathrm{O}_{2}$ was explained considering that the limiting oxidation reaction involved the attack of $\mathrm{BDD}\left({ }^{\circ} \mathrm{OH}\right)$ over cyanuric acid. For desmetryne and cyanazine, the effect of UVA light was more apparent because higher amounts of carboxylic acids like formic, oxamic and oxalic were produced from the degradation of their lateral groups. The optimum $\mathrm{pH}$ for all the processes was 2.0-4.0. Aromatic intermediates like desethylatrazine and desethyldesisopropylatrazine for atrazine, ammeline for desmetryne, and deisopropylatrazine, desethyldeisopropylatrazine and ammeline for cyanazine, which further evolved to cyanuric acid, were detected by HPLC. Fig. 7c exemplifies the reaction sequence proposed for the formation of this recalcitrant byproduct from atrazine [62]. In all cases,
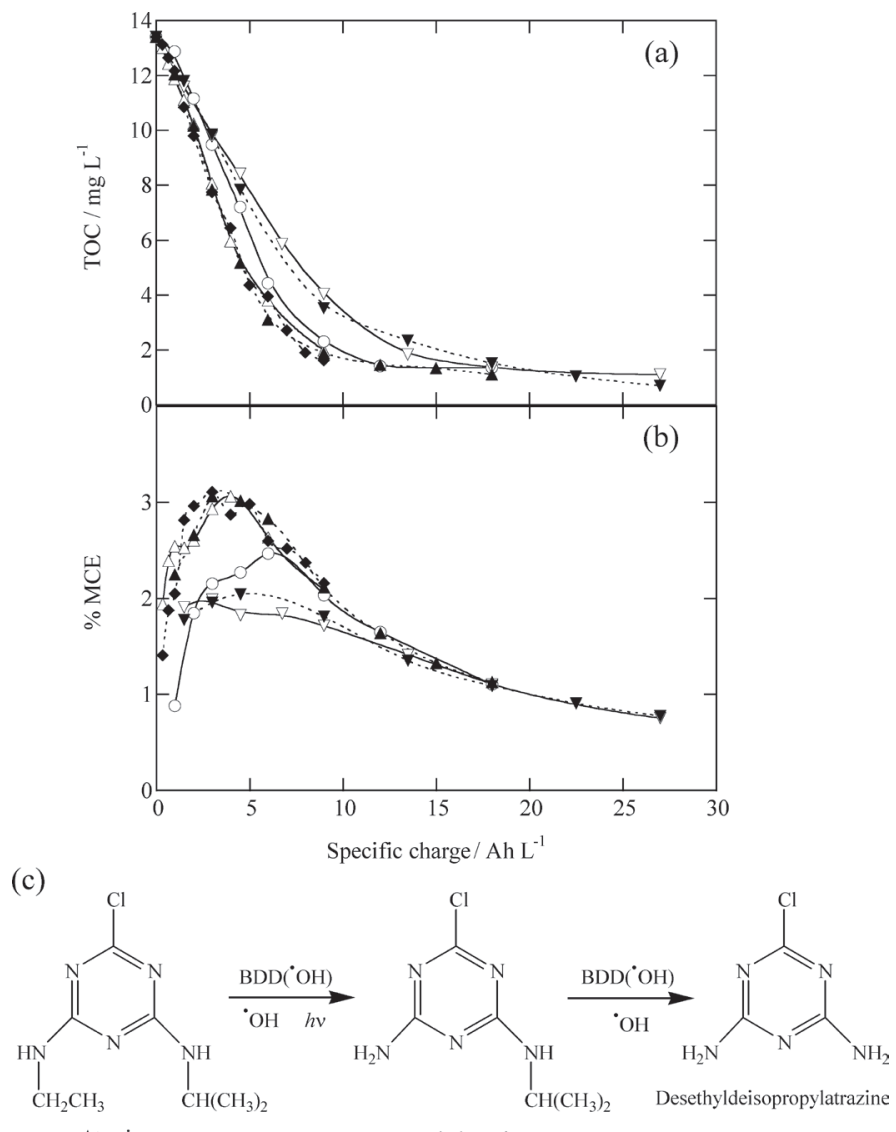

Atrazine

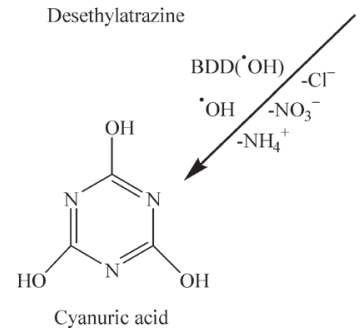

Fig. 7. Effect of applied current on (a) TOC removal and (b) mineralization current efficiency with consumed specific charge for the degradation of $100 \mathrm{~mL}$ of a $30 \mathrm{mg} \mathrm{L}^{-1}$ atrazine solution in $0.05 \mathrm{M}$ $\mathrm{Na}_{2} \mathrm{SO}_{4}$ of $\mathrm{pH} 3.0$ at $35^{\circ} \mathrm{C}$ by $(\triangle, \mathrm{O}, \nabla) \mathrm{AO}-\mathrm{H}_{2} \mathrm{O}_{2}$ and $(\bullet, \boldsymbol{\Delta}, \boldsymbol{\nabla})$ PEF with a BDD/GDE cell. Current: $(\triangle, \diamond) 100 \mathrm{~mA},(\mathrm{O}, \boldsymbol{\Delta}) 300 \mathrm{~mA}$ and $(\nabla, \boldsymbol{\nabla}) 450 \mathrm{~mA}$. (c) Proposed reaction sequence for the degradation of atrazine to cyanuric acid by EAOPs with a BDD anode. (Adapted from ref. [62]).

the initial $\mathrm{N}$ was mainly released as $\mathrm{NO}_{3}{ }^{-}$ion and the initial chlorine was lost as $\mathrm{Cl}^{-}$ion, which was oxidized to $\mathrm{Cl}_{2}$ at the BDD anode.

The effectiveness of the PEF process has been checked for an industrial chemical like sulfanilic acid (4-aminobenzenesulfonic acid) [65], which is widely used to synthesize pesticides, sulfonamide pharmaceuticals, sulfonated azo dyes, dye mordants, species, and food pigments. Using a stirred tank reactor like of Fig. 2a with a $3 \mathrm{~cm}^{2}$ BDD anode, it was found that $100 \mathrm{~mL}$ of $1.39 \mathrm{mM}$ sulfanilic acid only underwent a partial decontamination of $85 \%$ by EF until $100 \mathrm{~mA} \mathrm{~cm}{ }^{-2}$ at optimum conditions of $0.4 \mathrm{mM} \mathrm{Fe}^{2+}$ and $\mathrm{pH}$ 3.0. The rise in 
current density and substrate content led to an almost total mineralization. In contrast, the PEF process was more powerful giving almost total mineralization in less electrolysis time under comparable conditions. The kinetics for sulfanilic acid decay always obeyed a pseudo-first-order reaction. Hydroquinone and $p$-benzoquinone were detected as aromatic intermediates. Acetic, maleic, formic, oxalic and oxamic acids were identified and quantified as generated carboxylic acids. The fast photolysis of $\mathrm{Fe}$ (III)-carboxylate complexes, especially of the ultimate $\mathrm{Fe}(\mathrm{III})$-oxalate and $\mathrm{Fe}(\mathrm{III})$-oxamate species, under UVA radiation explained the greater oxidation ability of the PEF method. $\mathrm{NH}_{4}{ }^{+}$ion was released in both treatments, along with $\mathrm{NO}_{3}{ }^{-}$ion in much smaller proportion.

The degradation of several emerging aromatic drugs including analgesics/anti-inflammatories such as ibuprofen [66] and salicylic acid [67], the blood lipid regulator metabolite clofibric acid [68], antimicrobials such as chloramphenicol [69], chloroxylenol [70], enrofloxacin [71], flumequine [72], sulfamethazine [24] and sulfanilamide [73], and $\beta$-blockers such as atenolol [74], propranolol [75, 76] and metoprolol [23], has also been tested. Table 1 summarizes the time needed for the total disappearance of pharmaceuticals $\left(t_{\mathrm{TD}}\right)$ and the percentage of TOC removal at the end of comparative EF and PEF treatments of selected drug solutions in $0.05 \mathrm{M} \mathrm{Na}_{2} \mathrm{SO}_{4}$ at $\mathrm{pH} 3.0$. Trials were carried out with stirred tank reactors like of Fig. 2a containing a Pt or BDD anode and a GDE cathode, with a 6 W UVA lamp for PEF. Two pairs of electrodes, also using a CF cathode to enhance the $\mathrm{Fe}^{2+}$ regeneration in the system from $\mathrm{Fe}^{3+}$ reduction by reaction (16), were checked for the $\beta$-blockers [74-76]. Inspection of Table 1 confirms the higher oxidation ability of the PEF method compared to EF for all the pharmaceuticals tested, since $>95 \%$ TOC abatement (related to almost total mineralization) was always found for the former process under comparable conditions. More mineralization degree was reached with a BDD anode instead of $\mathrm{Pt}$, as expected for the higher oxidation power of generated $\mathrm{BDD}\left({ }^{\bullet} \mathrm{OH}\right)$. The drugs decay verified pseudo-first-order reactions and in most cases, Table 1 evidences practically the same $t_{\mathrm{TD}}$ values for both EF and PEF degradations, regardless of the anode (Pt or BDD) used. This indicates the pre-eminent reaction of aromatics with ${ }^{\circ} \mathrm{OH}$ formed from Fenton's reaction (5), but with poor production of this radical from photo-Fenton reaction (23). The greater TOC removal achieved in PEF is then due to the synergistic action of UVA light that is able to photolyze intermediates like Fe(III)-carboxylate complexes. Optimum degradation processes were obtained with $0.5-1.0 \mathrm{mM} \mathrm{Fe}^{2+}$ and at $\mathrm{pH}$ 3.0. It was also found that increasing current led to quicker mineralization due to the generation of more oxidizing species $\left(\mathrm{Pt}\left({ }^{\bullet} \mathrm{OH}\right)\right.$ or $\mathrm{BDD}\left({ }^{\bullet} \mathrm{OH}\right)$ and $\left.{ }^{\bullet} \mathrm{OH}\right)$, but with the concomitant loss of MCE due to the higher rates attained for the waste reactions (19)-(22). The presence of more organic matter enhanced the current efficiency, although longer time was needed for a given TOC abatement.

Note the study performed for the $\beta$-blockers using undivided combined four-electrode cells containing a GDE and a $\mathrm{CF}$ cathode to enhance the mineralization process from the fast $\mathrm{Fe}^{2+}$ regeneration at the latter cathode [74-76]. Shorter disappearance times and higher percentages of TOC removal for atenolol and propranolol were attained for the combined $\mathrm{Pt} / \mathrm{GDE}-\mathrm{Pt} / \mathrm{CF}$ and BDD/GDE-Pt/CF cells than for the single $\mathrm{Pt} / \mathrm{GDE}$ and $\mathrm{BDD} / \mathrm{GDE}$ ones in EF (see Table 1). Both drugs obeyed a pseudo-first-order kinetics with a rate at least 2.5 times higher in combined than in single cells. However, the fast destruction of $\mathrm{Fe}$ (III) complexes by UVA light in the analogous PEF processes led to similar mineralization degree for both kinds of cells when the most potent BDD anode was tested. This corroborates again the powerful synergistic influence of UVA irradiation in the latter method, which is even more potent to mineralize organic matter than the acceleration of Fenton's reaction (5) by increasing the rate of $\mathrm{Fe}^{2+}$ regeneration at the cathode. GC-MS and HPLC analysis of electrolyzed solutions allowed the detection of aromatic intermediates and generated carboxylic acids, leading to oxalic, oxamic and formic acids as ultimate byproducts. Fig. 8 presents the reaction sequence proposed for atenolol mineralization.

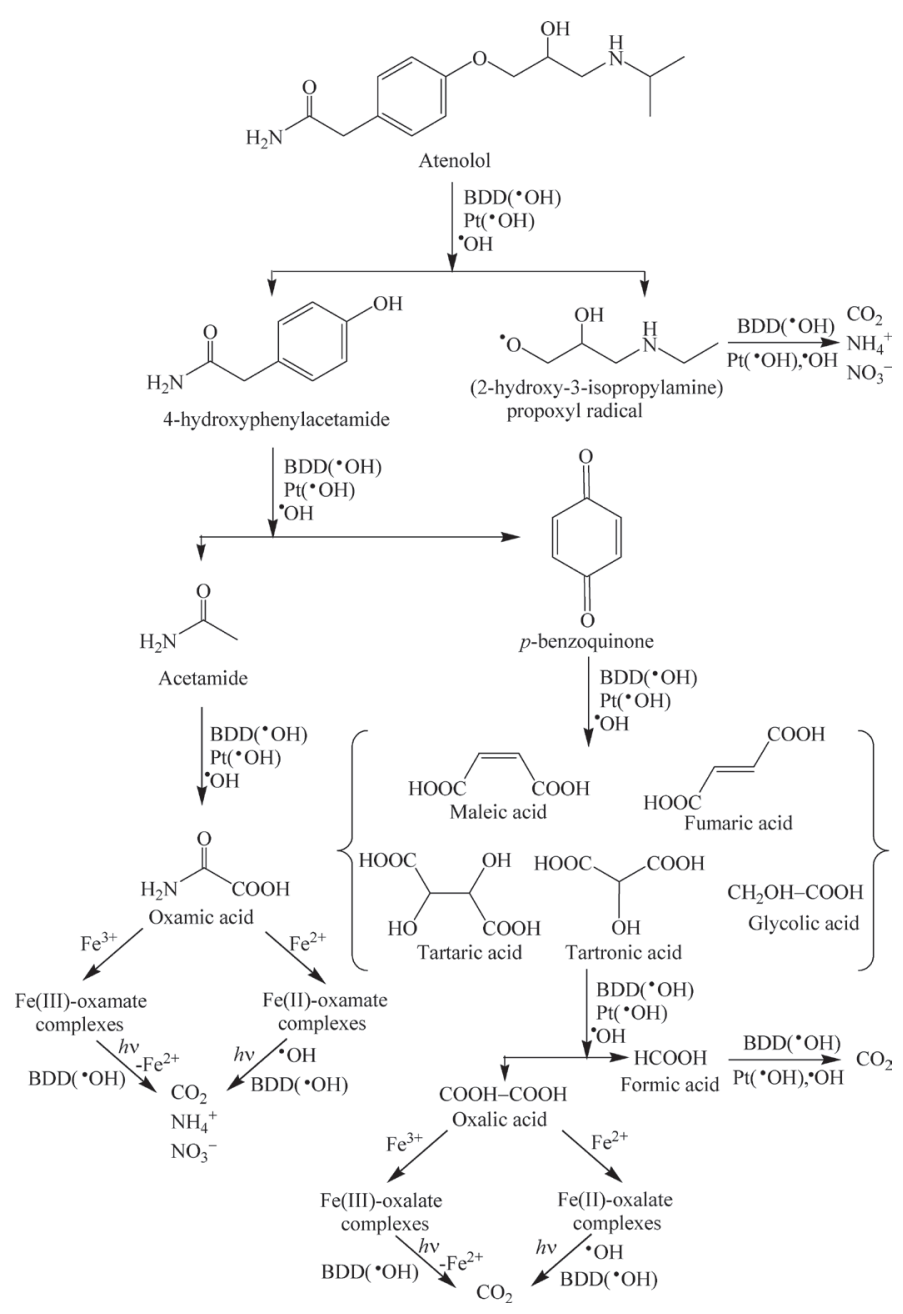

Fig. 8. Reaction sequence proposed for the EF degradation of atenolol using combined Pt/GDE-Pt/CF and BDD/GDE-Pt/CF felt cells. (Adapted from ref. [74]). 
Table 1. Time needed for the total disappearance of pharmaceuticals $\left(t_{\mathrm{TD}}\right)$ and percentage of TOC removal for drug solutions comparatively treated by EF and PEF processes using two-electrode or four-electrode cells with a Pt or BDD anode and a carbon felt $(\mathrm{CF})$ or gas $\left(\mathrm{O}_{2}\right.$ or air) diffusion electrode (GDE) cathode under selected conditions.

\begin{tabular}{|c|c|c|c|c|c|}
\hline Pharmaceutical & Method-Anode/Cathode & Solution $^{\mathrm{a}}$ & $t_{\mathrm{TD}}(\min )$ & $\begin{array}{l}\% \text { TOC } \\
\text { removal }\end{array}$ & Ref. \\
\hline Atenolol & $\begin{array}{l}\text { EF-Pt/GDE } \\
\text { EF-BDD/GDE } \\
\text { EF-Pt/GDE-Pt/CF } \\
\text { EF-BDD/GDE-Pt/CF } \\
\text { PEF-Pt/GDE } \\
\text { PEF-BDD/GDE } \\
\text { PEF-Pt/GDE-Pt/CF } \\
\text { PEF-BDD/GDE-Pt/CF }\end{array}$ & $\begin{array}{l}158 \mathrm{mg} \mathrm{L}^{-1} \text { drug with } 0.5 \mathrm{mM} \mathrm{Fe}^{2+}, 35^{\circ} \mathrm{C} \text {, at } 50 \\
\mathrm{~mA} \text { for two-electrode cells and } 50-12 \mathrm{~mA} \text { for } \\
\text { four-electrode cells during } 360 \mathrm{~min}\end{array}$ & $\begin{array}{c}60 \\
>60 \\
25 \\
30 \\
35 \\
35 \\
27 \\
25\end{array}$ & $\begin{array}{l}46 \\
77 \\
81 \\
90 \\
83 \\
95 \\
95 \\
97\end{array}$ & 74 \\
\hline Chloramphenicol & $\begin{array}{l}\text { EF-Pt/GDE } \\
\text { EF-BDD/GDE } \\
\text { PEF-Pt/GDE } \\
\text { PEF-BDD/GDE }\end{array}$ & $\begin{array}{l}245 \mathrm{mg} \mathrm{L}^{-1} \text { drug with } 0.5 \mathrm{mM} \mathrm{Fe}^{2+} \text { at } 100 \mathrm{~mA} \\
\text { and } 35^{\circ} \mathrm{C} \text { for } 360 \mathrm{~min}\end{array}$ & $\begin{array}{l}27 \\
27 \\
27 \\
27\end{array}$ & $\begin{array}{l}65 \\
81 \\
96 \\
99\end{array}$ & 69 \\
\hline Chloroxylenol & $\begin{array}{l}\text { EF-Pt/GDE } \\
\text { EF-BDD/GDE } \\
\text { PEF-Pt/GDE } \\
\text { PEF-BDD/GDE }\end{array}$ & $\begin{array}{l}100 \mathrm{mg} \mathrm{L}^{-1} \text { drug with } 1 \mathrm{mM} \mathrm{Fe}^{2+} \text { at } 100 \mathrm{~mA} \\
\text { and } 35^{\circ} \mathrm{C} \text { for } 360 \mathrm{~min}\end{array}$ & $\begin{array}{l}20 \\
20 \\
20 \\
20\end{array}$ & $\begin{array}{l}58 \\
82 \\
91 \\
98\end{array}$ & 70 \\
\hline Clofibric acid & $\begin{array}{l}\text { EF-Pt/GDE } \\
\text { EF-BDD/GDE } \\
\text { PEF-Pt/GDE } \\
\text { PEF-BDD/GDE }\end{array}$ & $\begin{array}{l}179 \mathrm{mg} \mathrm{L}^{-1} \text { drug with } 1 \mathrm{mM} \mathrm{Fe}^{2+} \text { at } 300 \mathrm{~mA} \\
\text { and } 35^{\circ} \mathrm{C} \text { for } 240 \mathrm{~min}\end{array}$ & $\begin{array}{l}7 \\
7 \\
7 \\
7\end{array}$ & $\begin{array}{c}73 \\
93 \\
92 \\
>96\end{array}$ & 68 \\
\hline Enrofloxacin & $\begin{array}{l}\text { EF-Pt/GDE } \\
\text { EF-BDD/GDE } \\
\text { PEF-Pt/GDE } \\
\text { PEF-BDD/GDE }\end{array}$ & $\begin{array}{l}158 \mathrm{mg} \mathrm{L}^{-1} \text { drug with } 0.5 \mathrm{mM} \mathrm{Fe}^{2+} \text { at } 100 \mathrm{~mA} \\
\text { and } 35^{\circ} \mathrm{C} \text { for } 360 \mathrm{~min}\end{array}$ & $\begin{array}{l}30 \\
30 \\
20 \\
20\end{array}$ & $\begin{array}{l}45 \\
78 \\
94 \\
96\end{array}$ & 71 \\
\hline Flumequine & $\begin{array}{l}\text { EF-BDD/GDE } \\
\text { PEF-BDD/GDE }\end{array}$ & $\begin{array}{l}62 \mathrm{mg} \mathrm{L}^{-1} \text { drug with } 2 \mathrm{mM} \mathrm{Fe}^{2+} \text { at } 100 \mathrm{~mA} \\
\text { and } 35^{\circ} \mathrm{C} \text { for } 360 \mathrm{~min}\end{array}$ & $\begin{array}{l}10 \\
10\end{array}$ & $\begin{array}{l}78 \\
95\end{array}$ & 72 \\
\hline Ibuprofen & $\begin{array}{l}\text { EF-Pt/GDE } \\
\text { EF-BDD/GDE } \\
\text { PEF-Pt/GDE } \\
\text { PEF-BDD/GDE }\end{array}$ & $\begin{array}{l}41 \mathrm{mg} \mathrm{L}{ }^{-1} \mathrm{drug} \text { (near saturation) with } 0.5 \mathrm{mM} \\
\mathrm{Fe}^{2+} \text { at } 100 \mathrm{~mA} \text { and } 35^{\circ} \mathrm{C} \text { for } 360 \mathrm{~min}\end{array}$ & $\begin{array}{l}40 \\
40 \\
40 \\
40\end{array}$ & $\begin{array}{l}58 \\
81 \\
83 \\
94\end{array}$ & 66 \\
\hline Salicylic acid & $\begin{array}{l}\text { EF-Pt/GDE } \\
\text { EF-BDD/GDE } \\
\text { PEF-Pt/GDE } \\
\text { PEF-BDD/GDE }\end{array}$ & $\begin{array}{l}164 \mathrm{mg} \mathrm{L}^{-1} \text { drug with } 0.5 \mathrm{mM} \mathrm{Fe}^{2+} \text { at } 100 \mathrm{~mA} \\
\text { and } 35^{\circ} \mathrm{C} \text { for } 180 \mathrm{~min}\end{array}$ & $\begin{array}{l}30 \\
30 \\
30 \\
30\end{array}$ & $\begin{array}{l}57 \\
73 \\
97 \\
96\end{array}$ & 67 \\
\hline Sulfamethazine & $\begin{array}{l}\text { EF-BDD/GDE } \\
\text { PEF-BDD/GDE }\end{array}$ & $\begin{array}{l}193 \mathrm{mg} \mathrm{L}^{-1} \text { drug with } 0.5 \mathrm{mM} \mathrm{Fe}{ }^{2+} \text { at } 100 \mathrm{~mA} \\
\text { and } 35^{\circ} \mathrm{C} \text { for } 360 \mathrm{~min}\end{array}$ & $\begin{array}{l}20 \\
10\end{array}$ & $\begin{array}{l}84 \\
95\end{array}$ & 24 \\
\hline Sulfanilamide & $\begin{array}{l}\text { EF-BDD/GDE } \\
\text { PEF-BDD/GDE }\end{array}$ & $\begin{array}{l}239 \mathrm{mg} \mathrm{L}^{-1} \text { drug with } 0.5 \mathrm{mM} \mathrm{Fe}^{2+} \text { at } 100 \mathrm{~mA} \\
\text { and } 35^{\circ} \mathrm{C} \text { for } 360 \text { min }\end{array}$ & $\begin{array}{l}15 \\
12\end{array}$ & $\begin{array}{l}90 \\
96\end{array}$ & 73 \\
\hline
\end{tabular}

${ }^{\text {a }}$ Experiments carried out with $100 \mathrm{~mL}$ solution in $0.05 \mathrm{M} \mathrm{Na}_{2} \mathrm{SO}_{4}$ at $\mathrm{pH} 3.0$ in a stirred tank reactor and with a $6 \mathrm{~W}$ UVA light for PEF.

\section{Degradation of Organic Pollutants by SPEF with a BDD anode}

The SPEF process was proposed by our group to make a less expensive and more viable EAOP by using sunlight as renew- able and inexpensive energy source. The removal of the drugs ibuprofen [66], salicylic acid [67], chloramphenicol [69] and enrofloxacin [71], as well as phthalic acid [77] which is an intermediate in the oxidation of naphthalenic rings, and the azo dye Sunset Yellow FCF [78] were comparatively studied 
by SPEF and other EAOPs (see Table 1) using a stirred tank reactor like of Fig. 2a equipped with a Pt or BDD anode and a GDE cathode, all with $3 \mathrm{~cm}^{2}$ area. In SPEF, the solution was submitted to an average UV intensity of sunlight of about 30$32 \mathrm{~W} \mathrm{~m}^{-2}$ and a mirror was placed at the bottom of the cell to better collect the solar energy.

Fig. 9a shows the TOC abatement with electrolysis time for the comparative EF, PEF and SPEF treatments of $100 \mathrm{~mL}$ of 41 $\mathrm{mg} \mathrm{L}^{-1}$ ibuprofen with $0.5 \mathrm{mM} \mathrm{Fe}^{2+}$ at $\mathrm{pH} 3.0,33.3 \mathrm{~mA} \mathrm{~cm}^{-2}$ and $25.0^{\circ} \mathrm{C}$. As expected, each process was enhanced using a $\mathrm{BDD}$ anode instead of $\mathrm{Pt}$ due to the greater oxidizing power of $\operatorname{BDD}\left({ }^{\bullet} \mathrm{OH}\right)$ than $\operatorname{Pt}\left({ }^{\bullet} \mathrm{OH}\right)$ to remove the contaminants. Application of UV light promoted the degradation process and an almost total mineralization was reached more rapidly in SPEF

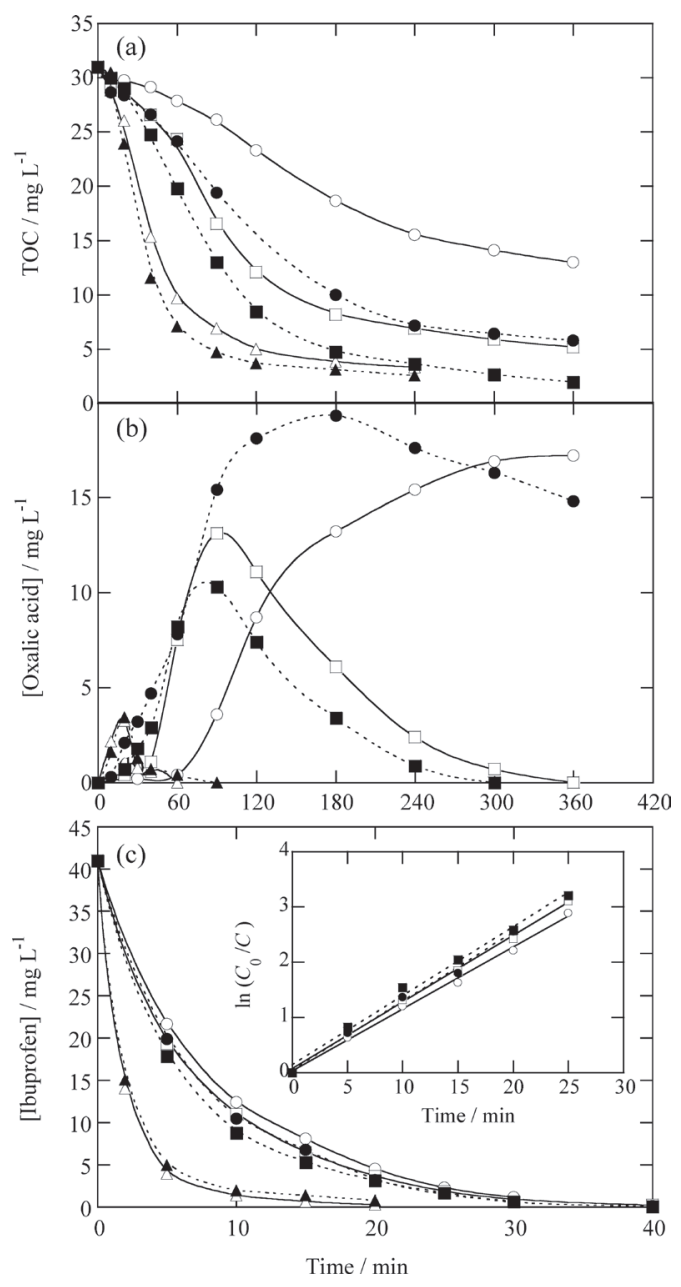

Fig. 9. (a) TOC decay and (b) evolution of generated oxalic acid for the degradation of $100 \mathrm{~mL}$ of $41 \mathrm{mg} \mathrm{L}^{-1}$ ibuprofen (close to saturation) with $0.05 \mathrm{M} \mathrm{Na}_{2} \mathrm{SO}_{4}$ and $0.5 \mathrm{mM} \mathrm{Fe}^{2+}$ at $\mathrm{pH} 3.0,33.3 \mathrm{~mA} \mathrm{~cm}^{-2}$ and $25.0{ }^{\circ} \mathrm{C}$ using stirred tank reactors with $3 \mathrm{~cm}^{2}$ electrode area and an $\mathrm{O}_{2}$-diffusion cathode. (O) EF with $\mathrm{Pt},(-) \mathrm{EF}$ with a BDD anode, ( $\square$ ) PEF with Pt under 6 W UVA light, (ם) PEF with BDD under 6 W UVA irradiation, $(\triangle)$ SPEF with Pt and $(\Delta)$ SPEF with BDD. (c) Decay of ibuprofen concentration. The inset panel presents the kinetic analysis assuming a pseudo-first-order reaction for the drug. (Adapted from ref. [66]). by the higher intensity of UV radiation from sunlight. Similar results were found for the other organics tested, showing that SPEF with BDD always led to quicker degradation. For all the treatments, $\mathrm{pH} 3.0$ was found optimal, near the optimum $\mathrm{pH}$ of 2.8 for Fenton's reaction (5), as expected if ${ }^{\bullet} \mathrm{OH}$ is the main oxidant of organic pollutants. Higher amounts of TOC were removed with increasing current density and substrate concentration.

GC-MS, reversed-phase HPLC and/or LC-MS analysis of treated solutions revealed the formation of aromatic intermediates like 4-ethylbenzaldehyde, 4-isobutylacetophenone, 4-isobutylphenol and 1-(1-hydroxyethyl)-4-isobutylbenzene for ibuprofen; 2,3-, 2,5- and 2,6-dihydroxybenzoic acids for salicylic acid; 9 aromatic products and 13 hydroxylated derivatives for chloramphenicol; polyols, ketones and $\mathrm{N}$-derivatives for enrofloxacin; 11 hydroxylated intermediates for phthalic acid; and 14 aromatic products and 34 hydroxylated derivatives, including benzenic, naphthalenic and phthalic acid compounds, for Sunset Yellow FCF. Ion-exclusion HPLC allowed the identification and quantification of different generated carboxylic acids, oxalic acid being the ultimate by-product accumulated in larger extent. Fig. 9b highlights the stability of the Fe(III)-oxalate complexes in EF, which were quickly removed in PEF and much more rapidly in SPEF by their fast photolysis from reaction (25). This behavior accounts for by the greatest mineralization degree attained in SPEF. Ion chromatography revealed that the initial $\mathrm{F}$ of enrofloxacin was completely transformed into $\mathrm{F}^{-}$ion and its initial $\mathrm{N}$ was primordially transformed into $\mathrm{NH}_{4}{ }^{+}$ion and in smaller proportion into $\mathrm{NO}_{3}{ }^{-}$ion. The same fate was found for the initial $\mathrm{N}$ of chloramphenicol, but for Sunset Yellow FCF about $80 \%$ of initial N was loss from the solution, probably as $\mathrm{N}_{2}$ and $\mathrm{N}_{\mathrm{x}} \mathrm{O}_{\mathrm{y}}$ species, suggesting a complex destruction of $N$-derivatives formed.

Fig. 9c illustrates a quite similar decay of ibuprofen concentration in EF and PEF, obeying a pseudo-first-order kinetics (see the inset panel), yielding $k_{1}=2.1 \times 10^{-3} \mathrm{~s}^{-1}$. In contrast, the reaction is strongly enhanced in SPEF, as expected if much more ${ }^{\bullet} \mathrm{OH}$ is produced from the action of the photo-Fenton reaction (23) as a result of the higher UV intensity of sunlight. This can also account for the higher oxidation ability of SPEF because primary products can be more rapidly destroyed leading intermediates that can be more quickly photolyzed by sunlight.

The SPEF treatment of organic pollutants was firstly scaled-up to the recirculation flow plant of $2.5 \mathrm{~L}$ with a BDD/ GDE filter-press cell coupled to a flat solar photoreactor schematized in Fig. 1a [34-37, 71, 79, 80]. The electrodes with 20 $\mathrm{cm}^{2}$ area were separated $1.2 \mathrm{~cm}$ and the solar photoreactor was a polycarbonate box of $600 \mathrm{~mL}$ of irradiated volume, built-up with a mirror at the bottom and tilted $30^{\circ}$ from the horizontal. Solutions with $50-300 \mathrm{mg} \mathrm{L}^{-1}$ of TOC in $0.05-0.10 \mathrm{M} \mathrm{Na}_{2} \mathrm{SO}_{4}$ with $0.5 \mathrm{mM} \mathrm{Fe}^{2+}$ at $\mathrm{pH} 3.0,50-100 \mathrm{~mA} \mathrm{~cm}^{-2}$ and liquid flow rate of $180-200 \mathrm{~L} \mathrm{~h}^{-1}$ were usually tested. Table 2 summarizes the high TOC removals with excellent MCE values, along with the corresponding $\mathrm{EC}_{\mathrm{TOC}}$ values, determined for selected $\mathrm{SPEF}$ assays. 
Table 2. Percentage of TOC removal, mineralization current efficiency and energy consumption per unit TOC mass for the degradation of several organic pollutants solutions by the SPEF process using a $2.5 \mathrm{~L}$ recirculation pre-pilot plant with a filter-press cell with $20 \mathrm{~cm}^{2}$ electrodes coupled to a solar flat photoreactor of $600 \mathrm{~mL}$ irradiated volume at about $30 \mathrm{~W} \mathrm{~m}^{-2}$ under selected conditions.

\begin{tabular}{|c|c|c|c|c|c|c|}
\hline Compound & Cell & Solution & $\%$ TOC removal & $\% \mathrm{MCE}$ & $\begin{array}{c}\mathrm{EC}_{\mathrm{TOC}} \\
\left(\mathrm{kWh} \mathrm{g}^{-1} \mathrm{TOC}\right)\end{array}$ & Ref. \\
\hline Acid Yellow 36 & $\mathrm{BDD} / \mathrm{GDE}$ & $\begin{array}{l}108 \mathrm{mg} \mathrm{L}^{-1} \text { dye in } 0.05 \mathrm{M} \mathrm{Na}_{2} \mathrm{SO}_{4} \text { and } \\
0.5 \mathrm{mM} \mathrm{Fe}^{2+}, \mathrm{pH} 3.0,0.5 \mathrm{~A} \text { and } 35^{\circ} \mathrm{C} \\
\text { for } 360 \mathrm{~min}\end{array}$ & 95 & 65 & 0.130 & 36 \\
\hline Acid Red 88 & \multirow[t]{2}{*}{ BDD/GDE } & $50 \mathrm{mg} \mathrm{L}^{-1}$ TOC of each dye in $0.1 \mathrm{M}$ & 98 & 20 & 0.490 & \multirow[t]{2}{*}{37} \\
\hline Acid Yellow 9 & & $\begin{array}{l}\mathrm{Na}_{2} \mathrm{SO}_{4} \text { and } 0.5 \mathrm{mM} \mathrm{Fe}^{2+} \text {, pH 3.0, } 1 \mathrm{~A} \\
\text { and } 35^{\circ} \mathrm{C} \text { for } 360 \mathrm{~min}\end{array}$ & 95 & 20 & 0.390 & \\
\hline Disperse Red 1 & \multirow[t]{2}{*}{ BDD/GDE } & $100 \mathrm{mg} \mathrm{L}^{-1} \mathrm{TOC}$ of each dye in $0.1 \mathrm{M}$ & 97 & 82 & 0.151 & \multirow[t]{2}{*}{79} \\
\hline Disperse Yellow 9 & & $\begin{array}{l}\mathrm{Na}_{2} \mathrm{SO}_{4} \text { and } 0.5 \mathrm{mM} \mathrm{Fe}^{2+} \text {, pH 3.0, } 1 \mathrm{~A} \\
\text { and } 35^{\circ} \mathrm{C} \text { for } 240 \mathrm{~min}\end{array}$ & 96 & 80 & 0.155 & \\
\hline Mecoprop & $\mathrm{BDD} / \mathrm{GDE}$ & $\begin{array}{l}634 \mathrm{mg} \mathrm{L}^{-1} \text { herbicide in } 0.05 \mathrm{M} \\
\mathrm{Na}_{2} \mathrm{SO}_{4} \text { and } 0.5 \mathrm{mM} \mathrm{Fe}^{2+} \text {, pH } 3.0,1 \mathrm{~A} \\
\text { and } 35^{\circ} \mathrm{C} \text { for } 540 \mathrm{~min}\end{array}$ & 97 & 93 & 0.129 & 35 \\
\hline
\end{tabular}

Similarly to found in the stirred tank reactor, SPEF was much more potent to mineralize organics than $\mathrm{EF}$ in the $2.5 \mathrm{~L}$ pre-pilot plant. As can be seen in Table 2, up to $637 \mathrm{mg} \mathrm{L}^{-1}$ of the pesticide mecoprop underwent $95 \%$ TOC reduction after a time as long as $540 \mathrm{~min}$ of SPEF at $50 \mathrm{~mA} \mathrm{~cm}^{-2}$ [35]. However, much faster degradation was found for the SPEF process of $o-$, $m$ - and $p$-cresol, attaining 95-98\% mineralization in only 180 min [34]. Analogously, almost total mineralization was also easily achieved for the dyes Acid Yellow 36 [36], Acid Red 88 [37], Acid Yellow 9 [37], Disperse Red 1 [79] and Disperse Red 3 [79] and for the pharmaceutical enrofloxacin [71]. For all these compounds, the MCE values increased at lower current density and higher contaminant concentration. For example, a maximum efficiency of $480 \%$ was obtained for the treatment of $1024 \mathrm{mg} \mathrm{L}^{-1}$ of $o$-cresol at $50 \mathrm{~mA} \mathrm{~cm}^{-2}$, which was reduced to $140 \%$ for $128 \mathrm{mg} \mathrm{L}^{-1}$. The very great MCE value found for this product evidences the great synergistic power of sunlight in SPEF. The same trend was obtained for $\mathrm{EC}_{\mathrm{TOC}}$. While this parameter was as high as $0.259 \mathrm{kWh} \mathrm{g}^{-1}$ TOC after $240 \mathrm{~min}$ of EF degradation of $100 \mathrm{mg} \mathrm{L}^{-1}$ TOC of Disperse Red 1 at $50 \mathrm{~mA}$ $\mathrm{cm}^{-2}$, it was reduced to $0.151 \mathrm{kWh} \mathrm{g}^{-1}$ TOC $(\mathrm{EC}=14.2 \mathrm{kWh}$ $\mathrm{m}^{-3}$ ) for the comparative SPEF with $97 \%$ mineralization and $82 \%$ current efficiency. This corroborates that SPEF is much more economic than EF.

The performance of SPEF was enhanced by combining $\mathrm{Fe}^{2+}$ and $\mathrm{Cu}^{2+}$ as co-catalysts, as found for Disperse Blue 3 [80]. Figs. 10a and b illustrate that the use of $0.5 \mathrm{mM} \mathrm{Fe}^{2+}+0.1$ $\mathrm{mM} \mathrm{Cu}^{2+}$. allowed $>95 \%$ TOC abatement in the presence and absence of $200 \mathrm{mg} \mathrm{L}^{-1}$ dye with $\mathrm{EC}_{\mathrm{TOC}}<0.080 \mathrm{kWh} \mathrm{g}^{-1} \mathrm{TOC}$, more rapidly and less expensive than using $0.5 \mathrm{mM} \mathrm{Fe}^{2+}$ alone. This corroborates the attack of ${ }^{\bullet} \mathrm{OH}$ on $\mathrm{Cu}(\mathrm{II})$ complexes of

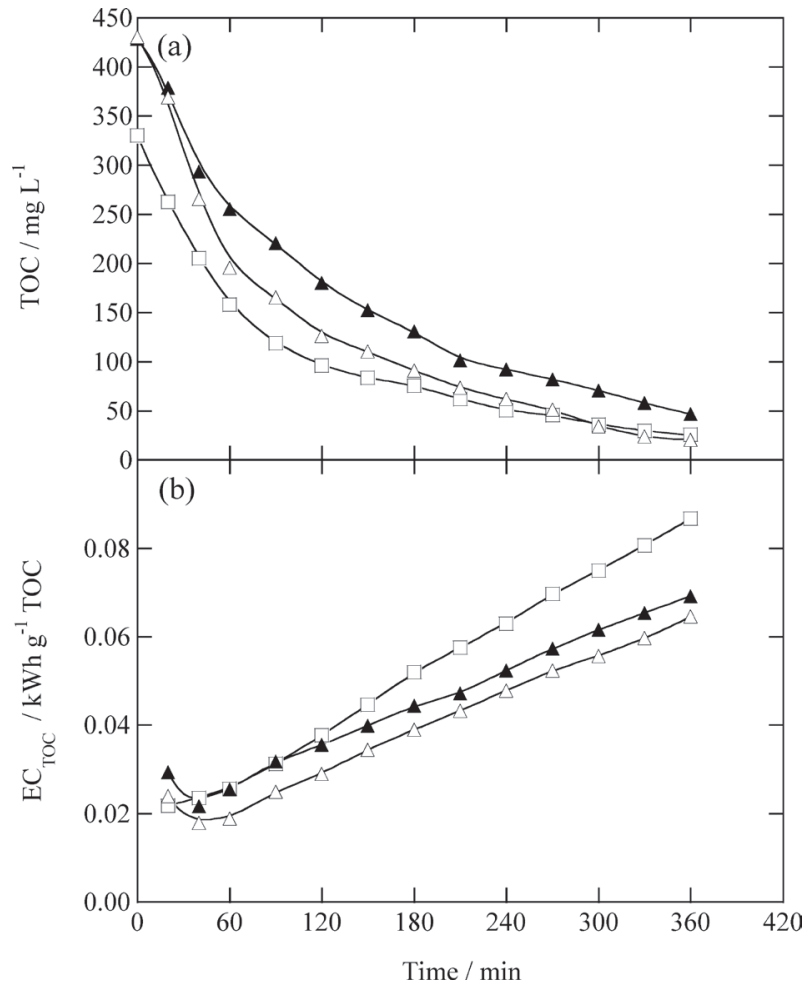

Fig. 10. Variation of (a) TOC and (b) energy consumption per unit TOC mass with electrolysis time for the SPEF treatment of $2.5 \mathrm{~L}$ of a simulated textile dyeing wastewater $\left(330 \mathrm{mg} \mathrm{L}^{-1} \mathrm{TOC}\right.$ from additives) with $0.10 \mathrm{M} \mathrm{Na}_{2} \mathrm{SO}_{4}$ of $\mathrm{pH} 3.0$ at $1.0 \mathrm{~A}, 35{ }^{\circ} \mathrm{C}$ and liquid flow rate of $200 \mathrm{~L} \mathrm{~h}^{-1}$. The solutions contained: $(\square) 0.5 \mathrm{mM} \mathrm{Fe}^{2+}+0.1 \mathrm{mM}$ $\mathrm{Cu}^{2+},(\boldsymbol{\Delta}) 0.5 \mathrm{mM} \mathrm{Fe}^{2+}$ and $200 \mathrm{mg} \mathrm{L}^{-1}$ Disperse Blue 3 and $(\triangle) 0.5$ $\mathrm{mM} \mathrm{Fe}{ }^{2+}+0.1 \mathrm{mM} \mathrm{Cu}^{2+}$ and $200 \mathrm{mg} \mathrm{L}^{-1}$ Disperse Blue 3. (Adapted from ref. [80]). 
generated carboxylic acids like oxalic and oxamic (see Figs. 5c and d), competitively formed with Fe(III)-carboxylate ones.

All the organic pollutants tested in the $2.5 \mathrm{~L}$ pre-pilot plant dropped at similar rate in EF and SPEF obeying a pseudo-firstorder kinetics and their $k_{1}$ value increased with rising current density and decreasing pollutant concentrations. Aromatic intermediates were detected in several cases. For example, 2methyl- $p$-benzoquinone for $o$ - and $m$-cresol, 5-methyl-2-hydroxy-p-benzoquinone for $p$-cresol, 2-methylhydroquinone, 2-methyl-p-benzoquinone and 4-chloro-o-cresol for mecoprop and up to 15 anthraquinonic and phthalic acid derivatives for Disperse Blue 3. Analysis of final carboxylic acids confirmed the quick photolysis of $\mathrm{Fe}(\mathrm{III})$-oxalato complexes, but the formation of other more recalcitrant acids like acetic and oxamic slowed the mineralization process. $\mathrm{Cl}^{-}$ion was loss in mecoprop degradation [35], whereas $\mathrm{SO}_{4}{ }^{2-}, \mathrm{NH}_{4}{ }^{+}$and/or $\mathrm{NO}_{3}{ }^{-}$ ions were loss in the mineralization of dyes $[36,37,78]$.

The study of the SPEF process was lately extended to a 10 L pre-pilot plant, schematized in Fig. 11a, where the electrochemical filter-press reactor contained electrodes of $90.3 \mathrm{~cm}^{2}$ area and was coupled to a $1.57 \mathrm{~L}$ compound parabolic collectors

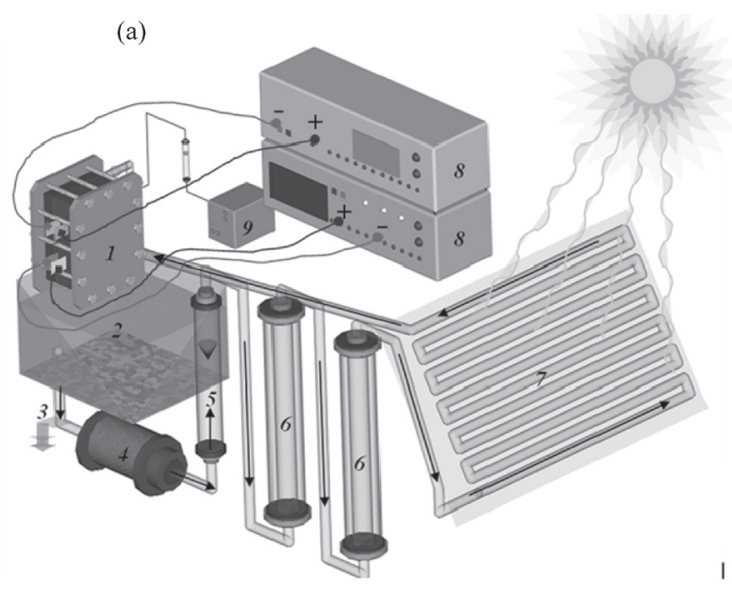

(b)

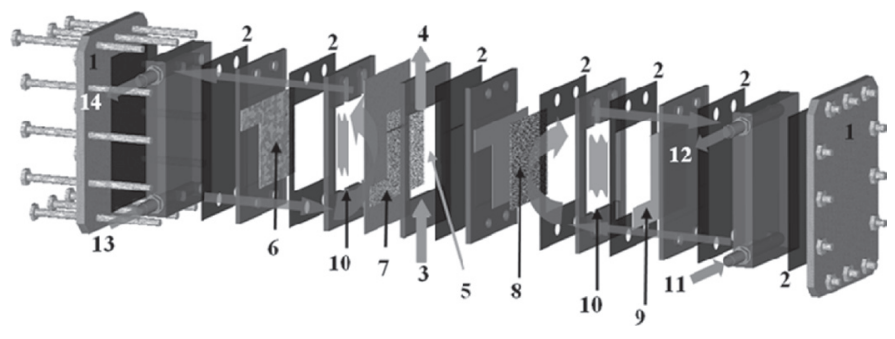

Fig. 11. (a) Experimental setup of a $10 \mathrm{~L}$ recirculation pre-pilot plant for the SPEF treatment of organic pollutants. (1) Flow electrochemical cell, (2) reservoir, (3) sampling, (4) peristaltic pump, (5) flowmeter, (6) heat exchanger, (7) solar CPCs photoreactor, (8) power supply and (9) air pump. (b) Sketch of a combined filter-press electrochemical ce11. (1) End plate, (2) gasket, (3) air inlet, (4) air outlet, (5) air chamber, (6) $90.3 \mathrm{~cm}^{2}$ BDD anode, (7) $90.3 \mathrm{~cm}^{2}$ GDE cathode, (8) $90.3 \mathrm{~cm}^{2} \mathrm{CF}$ cathode, (9) $90.3 \mathrm{~cm}^{2} \mathrm{Pt}$ anode, (10) liquid compartment, (11) liquid inlet in the cell, (12) liquid outlet of the Pt/CF pair connected to 13, (13) liquid inlet in the BDD/GDE pair and (14) liquid outlet of the cell. (Adapted from ref. [81]).

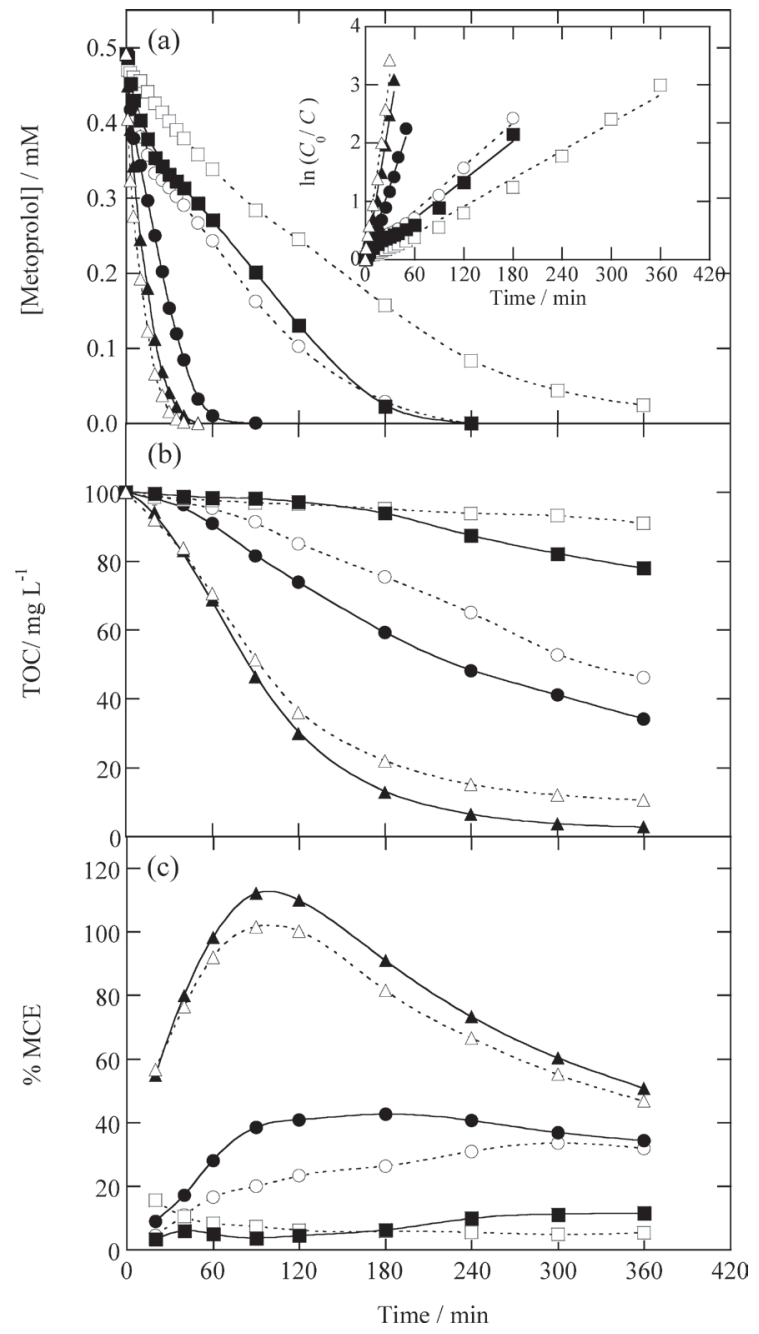

Fig. 12. (a) Concentration metoprolol decay during the EF and SPEF treatments of $10 \mathrm{~L}$ of $0.492 \mathrm{mM}$ drug in $0.10 \mathrm{M} \mathrm{Na}_{2} \mathrm{SO}_{4}$ with 0.5 $\mathrm{mM} \mathrm{Fe}{ }^{2+}$ at $\mathrm{pH} 3.0$ and $35^{\circ} \mathrm{C}$ in the pre-pilot plant of Fig. 11a with single and combined cells. The inset panel depicts the kinetic analysis assuming a pseudo-first-order reaction for the drug. (b) TOC removal and (c) mineralization current efficiency for the degradation of 0.246 $\mathrm{mM}$ metoprolol tartrate under the same conditions. ( $\square$ ) EF in Pt/GDE cell at $3.0 \mathrm{~A},(\boldsymbol{\square}) \mathrm{EF}$ in $\mathrm{Pt} / \mathrm{GDE}-\mathrm{Pt} / \mathrm{CF}$ cell at 3.0-0.4 A, (O) EF in $\mathrm{BDD} / \mathrm{GDE}$ cell at $3.0 \mathrm{~A},(\mathbf{O}) \mathrm{EF}$ in $\mathrm{BDD} / \mathrm{GDE}-\mathrm{Pt} / \mathrm{CF}$ cell at 3.0-0.4 $\mathrm{A},(\triangle)$ SPEF in Pt/GDE-Pt/CF cell at 3.0-0.4 $\mathrm{A}$ and (A) SPEF in $\mathrm{BDD} / \mathrm{GDE}-\mathrm{Pt} / \mathrm{CF}$ cell at 3.0-0.4 A. (Adapted from ref. [81]).

(CPCs) as the solar photoreactor. This plant has been used by Isarain et al. [81] to extent the study of the SPEF degradation of $100 \mathrm{mg} \mathrm{L}^{-1}$ TOC of solutions with the $\beta$-blockers atenolol, metoprolol tartrate and propranolol hydrochloride in $0.10 \mathrm{M}$ $\mathrm{Na}_{2} \mathrm{SO}_{4}$ with $0.5 \mathrm{mM} \mathrm{Fe}^{2+}$ at $\mathrm{pH} 3.0$ using single $\mathrm{Pt} / \mathrm{ADE}$ and $\mathrm{BDD} / \mathrm{ADE}$ cells and their combination with a $\mathrm{Pt} / \mathrm{CF}$ cell to enhance $\mathrm{Fe}^{2+}$ regeneration from $\mathrm{Fe}^{3+}$ reduction. As an example, Fig. $11 \mathrm{~b}$ shows a sketch of the combined BDD/GDE-Pt/CF cell used. For metoprolol tartrate, Figs. 12a, b and c evidence the superiority of combined cells over single ones, BDD over Pt and SPEF over EF regarding the decay kinetics of the substrate, TOC removal and MCE, respectively. This can be related to the larger generation of ${ }^{\bullet} \mathrm{OH}$ from Fenton's reaction (5) in the com- 
bined cells, the higher oxidizing power of $\operatorname{BDD}\left({ }^{\circ} \mathrm{OH}\right)$ and the photolytic action of sunlight in SPEF, as can also be deduced from the relative pseudo-first-order decay kinetics shown in the inset of Fig. 12a for the different cells checked. Although the combined BDD/GDE-Pt/CF cell was the most potent system, the lowest $\mathrm{EC}_{\mathrm{TOC}}$ of $0.080 \mathrm{kWh} \mathrm{g}^{-1} \mathrm{TOC}$ with $88-93 \%$ mineralization was obtained for the $\mathrm{Pt} / \mathrm{GDE}-\mathrm{Pt} / \mathrm{CF}$ one.

\section{Conclusions}

EAOPs based on Fenton's reaction chemistry such as EF, PEF and SPEF are viable to remove toxic and refractory organic pollutants from acidic waters because they allow high mineralization rates with good current efficiency. These simple, safe and environmentally friendly technologies can be easily scaled-up from stirred tank reactors to industrial level using recirculation flow plants. The current electrochemical technology permits the use of very stable and powerful anodes like BDD thin films and several carbonaceous cathodes for an efficient $\mathrm{H}_{2} \mathrm{O}_{2}$ generation. The main drawback for industrial application of these EAOPs is the electrical cost for running the electrochemical cell since the energy cost required for the UV lamp in PEF can be avoided when sunlight is used in SPEF. The possible coupling of photovoltaic systems to provide inexpensive electrical energy to the electrochemical reactor could be an excellent alternative way that may be tested in the next future to solve this problem. The coupling of the reactor with efficient solar CPCs photoreactors is another interesting possibility for enhancing the degradation process. It has been shown that the SPEF treatment of organic pollutants with a BDD anode is more efficient and less expensive than using other EAOPs under comparable conditions. In EF, PEF and SPEF with BDD, the mineralization rate was slowed as applied current dropped and pollutant concentration increased, but with greater MCE and lower energy consumption. The contaminant decay usually followed a pseudo-first-order kinetics. Aromatic intermediates were oxidized by generated ${ }^{\circ} \mathrm{OH}$ giving short-linear carboxylic acids that form Fe(III) complexes. Most of Fe(III)-carboxylate species were much more rapidly photolyzed by the more potent UV radiation supplied by sunlight in SPEF than by artificial UVA lamps in PEF. Heteroatoms present in organics were also mineralized and released as inorganic ions such as $\mathrm{F}^{-}, \mathrm{Cl}^{-}$, $\mathrm{SO}_{4}{ }^{2-}, \mathrm{NH}_{4}{ }^{+}$and $\mathrm{NO}_{3}{ }^{-}$.

\section{Acknowledgements}

The author thanks financial support from MICINN (Ministerio de Ciencia e Innovación, Spain) under project CTQ201016164/BQU, co-financed with FEDER funds.

\section{References}

1. Khetan, S. K.; Collins, T. J. Chem. Rev. 2007, 107, 2319.

2. Martínez-Huitle, C. A.; Brillas, E. Appl. Catal. B: Environ. 2009, $87,105$.
3. Kümmerer, K. Chemosphere 2009, 75, 417.

4. Luo, Y.; Xu, L.; Rysz, M.; Wang, Y.; Zhang, H.; Alvarez, P. J. J. Environ. Sci. Technol. 2011, 45, 1827.

5. Esplugas, S.; Bila, D. M.; Krause, L. G. T.; Dezotti, M. J. Hazard. Mater. 2007, 149, 631.

6. Klavarioti, M.; Mantzavinos, D.; Kassinos, D. Environ. Int. 2009, 35, 402.

7. Panizza, M.; Cerisola, G. Chem. Rev. 2009, 109, 6541.

8. Brillas, E.; Sirés, I.; Oturan, M. A. Chem. Rev. 2009, 109, 6570.

9. Serra, A.; Domènech, X.; Arias, C.; Brillas, E.; Peral, J. Appl. Catal. B: Environ. 2009, 89, 12.

10. Sirés, I.; Brillas, E. Environ. Int. 2012, 40, 212.

11. Pletcher, D. Acta Chem. Scand. 1999, 53, 745.

12. Foller, P. C.; Bombard, R. T. J. Appl. Electrochem. 1995, 25, 613.

13. Alvarez Gallegos, A.; Vergara García, Y.; Zamudio, A. Sol. Energy Mater. Sol. Cells 2005, 88, 157.

14. Khataee, A. R.; Zarei, M. Desalination 2011, 278, 117.

15. Khataee, A. R.; Vahid, B.; Behjati, B.; Safarpour, M. Environ. Progr. Sust. Energy 2013, 32, 557.

16. Khataee, A. R.; Safarpour, M.; Naseri, A.; Zarei, M. J. Electroanal. Chem. 2012, 672, 53.

17. Kaplan, F.; Hesenov, A.; Gozmen, B.; Erbatur, O.; Environ. Technol. 2011, 32, 685.

18. Murati, M.; Oturan, N.; Aaron, J. J.; Dirany, A.; Tassin, B.; Zdravkovski, Z.; Oturan, M. A. Environ. Sci. Pollut. Res. 2012, $19,1563$.

19. Wang, A.; Qu, J.; Liu, H.; Ru, J. Appl. Catal. B: Environ. 2008, 84, 393.

20. Wang, A.; Li, Y. -Y.; Estrada, A. L. Appl. Catal. B: Environ. 2011, 102,378

21. Brillas, E.; Baños, M. A.; Skoumal, M.; Cabot, P. L.; Garrido, J.A.; Rodríguez, R. M. Chemosphere 2007, 68, 199.

22. Expósito, E.; Sánchez-Sánchez, C. M.; Montiel, V. J. Electrochem. Soc. 2007, 154, E116.

23. Isarain-Chávez, E.; Garrido, J. A.; Rodríguez, R. M.; Centellas, F.; Arias, C.; Cabot, P. L.; Brillas, E. J. Phys. Chem. A 2011, 115, 1234.

24. El-Ghenymy, A.; Rodríguez, R. M.; Arias, C.; Centellas, F.; Garrido, J. A.; Cabot, P. L.; Brillas, E. J. Electroanal. Chem. 2013, $701,7$.

25. Cruz-González, K.; Torres-López, O.; García-León, A. M.; Brillas, E.; Hernández-Ramírez, A.; Peralta-Hernández, J. M. Desalination 2012, 286, 63.

26. Sun, Y.; Pignatello, J. J. Environ. Sci. Technol. 1993, 27, 304.

27. Oturan, M. A.; Oturan, N.; Aaron, J. J. Actual. Chimique 2004, $277-278,57$.

28. Sirés, I.; Garrido, J. A.; Rodríguez, R. M.; Brillas, E.; Oturan, N.; Oturan, M. A. Appl. Catal. B: Environ. 2007, 72, 382.

29. Marselli, B.; Garcia-Gomez, J.; Michaud, P. A.; Rodrigo, M. A.; Comninellis, Ch. J. Electrochem. Soc. 2003, 150, D79.

30. Panizza, M.; Cerisola, G. Electrochim. Acta, 2005, 51, 191.

31. Panizza, M.; Michaud, P. A.; Cerisola, G.; Comninellis, Ch. J. Electroanal. Chem. 2001, 507, 206.

32. Flox, C.; Cabot, P. L.; Centellas, F.; Garrido, J. A.; Rodríguez, R. M.; Arias, C.; Brillas, E. Chemosphere 2006, 64, 892-902.

33. Zuo, Y.; Hoigné, J. Environ. Sci. Technol. 1992, 26, 1014.

34. Flox, C.; Cabot, P. L.; Centellas, F.; Garrido, J. A.; Rodríguez, R. M.; Arias, C.; Brillas, E. Appl. Catal. B: Environ. 2007, 75, 17.

35. Flox, C.; Garrido, J. A.; Rodríguez, R. M.; Cabot, P. L.; Centellas, F.; Arias, C.; Brillas, E. Catal. Today 2007, 129, 29.

36. Ruiz, E. J.; Arias, C.; Brillas, E.; Hernández-Ramírez, A.; PeraltaHernández, J. M. Chemosphere 2011, 82, 495.

37. Ruiz, E. J.; Hernández-Ramírez, A.; Peralta-Hernández, J. M.; Arias, C.; Brillas, E. Chem. Eng. J. 2011, 171, 385.

38. Brillas, E.; Boye, B.; Sirés, I.; Garrido, J. A.; Rodríguez, R. M.; Arias, C.; Cabot, P. -L.; Comninellis, Ch. Electrochim. Acta 2004, $49,4487$. 
39. Montanaro, D.; Petrucci, E.; Merli, C. J. Appl. Electrochem. 2008, $38,947$.

40. Rodríguez De León, N. E.; Cruz-González, K.; Torres-López, O.; Ramírez-Hernández, A.; Guzmán-Mar, J. L.; Martínez-Huitle, C. A.; Peralta-Hernández, J. M. ECS Transactions 2009, 20, 283.

41. Abdessalem, A. K.; Oturan, M. A.; Oturan, N.; Bellakhal, N.; Dachraoui, M. Int. J. Environ. Anal. Chem. 2010, 90, 468.

42. Oturan, N.; Hamza, M.; Ammar, S.; Abdelhedi, R.; Oturan, M. A. J. Electroanal. Chem. 2011, 661, 66.

43. Oturan, N.; Brillas, E.; Oturan, M. A. Environ. Chem. Lett. 2012, 10,165

44. Almomani, F.; Baranova, E. A. Water Sci. Technol. 2012, 66, 465.

45. Sirés, I.; Oturan, N.; Oturan, M. A.; Rodríguez, R. M.; Garrido, J. A.; Brillas, E. Electrochim. Acta 2007, 52, 5493.

46. Hammami, S.; Bellakhal, N.; Oturan, N.; Oturan, M. A.; Dachraoui, M. Chemosphere 2008, 73, 678.

47. Ozcan, A.; Sahin, Y.; Koparal, A. S.; Oturan, M. A. Appl. Catal. B: Environ. 2009, 89, 620.

48. Cruz-González, K.; Torres-López, O.; García-León, A.; GuzmánMar, J. L.; Reyes, L. H.; Hernández-Ramírez, A.; Peralta-Hernández, J. M. Chem. Eng. J. 2010, 160, 199.

49. Randazzo, S.; Scialdone, O.; Brillas, E.; Sirés, I. J. Hazard. Mater. 2011, 192, 1555.

50. Garcia-Segura, S.; Centellas, F.; Arias, C.; Garrido, J. A.; Rodríguez, R. M.; Cabot, P. L.; Brillas, E. Electrochim. Acta 2011, 58, 303.

51. Dirany, A.; Sirés, I.; Oturan, N.; Ozcan, A.; Oturan, M. A. Environ. Sci. Technol. 2012, 46, 4074.

52. Almomani, F.; Baranova, E. A. Environ. Technol. 2013, 34, 1473.

53. Isarain-Chavez, E.; de la Rosa, C.; Martínez-Huitle, C. A.; PeraltaHernández, J. M. Int. J. Electrochem. Sci. 2013, 8, 3084.

54. Loaiza-Ambuludi, S.; Panizza, M.; Oturan, N.; Ozcan, A.; Oturan, M. A. J. Electroanal. Chem. 2013, 702, 31.

55. Brillas, E.; Bastida, R. M.; Llosa, E.; Casado, J. J. Electrochem. Soc. 1995, 142, 1733.

56. Oturan, M. A.; Guivarch, E.; Oturan, N.; Sirés, I. Appl. Catal. B: Environ. 2008, 82, 244.

57. Flox, C.; Ammar, S.; Arias, C.; Brillas, E.; Vargas-Zavala, A. V.; Abdelhedi, R. Appl. Catal. B: Environ. 2006, 67, 93.

58. Sharma, V. K.; Millero, F. J. Environ. Sci. Technol. 1988, 22, 768.

59. Gallard, H.; De Laat, J.; Legube, B. Rev. Sci. Eau 1999, 12, 713.

60. Garcia-Segura, S.; El-Ghenymy, A.; Centellas, F.; Rodríguez, R. M.; Arias, C.; Garrido, J. A.; Cabot, P. L.; Brillas, E. J. Electroanal. Chem. 2012, 681, 36.
61. Almeida, L. C.; Garcia-Segura, S.; Arias, C.; Bocchi, N.; Brillas, E. Chemosphere 2012, 89, 751.

62. Borràs, N.; Oliver, R.; Arias, C.; Brillas, E. J. Phys. Chem. A 2010, 114, 6613.

63. Borras, N.; Arias, C.; Oliver, R.; Brillas, E. Chemosphere 2011, $85,1167$.

64. Borràs, N.; Arias, C.; Oliver, R.; Brillas, E. J. Electroanal. Chem. 2013, 689, 158.

65. El-Ghenymy, A.; Garrido, J. A.; Centellas, F.; Arias, C.; Cabot, P. L.; Rodríguez, R. M.; Brillas, E. J. Phys. Chem. A 2012, 116, 3404.

66. Skoumal, M.; Rodríguez, R. M.; Cabot, P. L.; Centellas, F.; Garrido, J. A.; Arias, C.; Brillas, E.; Electrochim. Acta 2009, 54, 2077.

67. Guinea, E.; Arias, C.; Cabot, P. L.; Garrido, J. A.; Rodríguez, R. M.; Centellas, F.; Brillas, E.; Water Res. 2008, 42, 499.

68. Sirés, I.; Centellas, F.; Garrido, J. A.; Rodríguez, R. M.; Arias, C.; Cabot, P. L.; Brillas, E. Appl. Catal. B: Environ. 2007, 72, 373.

69. Garcia-Segura, S.; Cavalcanti, E. B.; Brillas, E. Appl. Catal. B: Environ. 2014, 144, 588.

70. Skoumal, M.; Arias, C.; Cabot, P. L.; Centellas, F.; Garrido, J. A.; Rodríguez, R. M.; Brillas, E. Chemosphere 2008, 71, 1718.

71. Guinea, E.; Garrido, J. A.; Rodríguez, R. M.; Cabot, P. L.; Arias, C.; Centellas, F.; Brillas, E. Electrochim. Acta 2010, 55, 2101.

72. Garcia-Segura, S.; Garrido, J. A.; Rodríguez, R. M.; Cabot, P. L.; Centellas, F.; Arias, C.; Brillas, E. Water Res. 2012, 46, 2067.

73. El-Ghenymy, A.; Oturan, N.; Oturan, M. A.; Garrido, J. A.; Cabot, P. L.; Centellas, F.; Rodríguez, R. M.; Brillas, E. Chem. Eng. J. 2013, 234, 115.

74. Isarain-Chávez, E.; Arias, C.; Cabot, P. L.; Centellas, F.; Rodríguez, R. M.; Garrido, J. A.; Brillas, E. Appl. Catal. B: Environ. 2010, 96, 361 .

75. Isarain-Chávez, E.; Rodríguez, R. M.; Garrido, J. A.; Arias, C.; Centellas, F.; Cabot, P. L.; Brillas, E. Electrochim. Acta 2010, 56, 215.

76. Isarain-Chávez, E.; Cabot, P. L.; Centellas, F.; Rodríguez, R. M.; Arias, C.; Garrido, J. A.; Brillas, E. J. Hazard. Mater. 2011, 185, 1228.

77. Garcia-Segura, S.; Salazar, R.; Brillas, E. Electrochim. Acta 2013, 113, 609 .

78. Moreira, F. C.; Garcia-Segura, S.; Vilar, V. J. P.; Boaventura, R. A. R.; Brillas, E. Appl. Catal. B: Environ. 2013, 142-143, 877.

79. Salazar, R.; Garcia-Segura, S.; Ureta-Zañartu, M. S.; Brillas, E. Electrochim. Acta 2011, 56, 6371.

80. Salazar, R.; Brillas, E.; Sirés, I. Appl. Catal. B: Environ. 2012, 115-116, 107.

81. Isarain-Chávez, E.; Rodríguez, R. M.; Cabot, P. L.; Centellas, F.; Arias, C.; Garrido, J. A.; Brillas, E. Water Res. 2011, 45, 4119. 